\title{
BANDED CONTRACTS, MEDIATING INSTITUTIONS, AND CORPORATE GOVERNANCE: A NATURALIST ANALYSIS OF CONTRACTUAL THEORIES OF THE FIRM
}

\author{
TIMOTHY L. FORT* AND JAMES J. NOONE**
}

\begin{abstract}
There are a spate of books . . that suggest that business is a "mystical experience [or] a "religious happening." And their mantra is lifted directly from the lips of Yoda-"experience the force." No matter how sincere and well intentioned some of these texts are-enough already, please! ${ }^{1}$
\end{abstract}

Size matters not. Look at me. Judge me by my size, do you? Hm? Mmmm.

And well you should not. For my ally is the Force.

And a powerful ally it is.

Life creates it, makes it grow.

Its energy surrounds us and binds us.

Luminous beings are we. . . not this crude matter.

You must feel the Force around you.

Here, hidden between you . . me . . the tree . . the rock . . everywhere!

Yes, even between this land and that ship. ${ }^{2}$

\section{INTRODUCTION}

Basing a theory of moral business on a celluloid science fiction creation may not foster its intellectual stature, but one could substitute quotes similar to Yoda's from Buddhism, ${ }^{3}$ Hinduism, ${ }^{4}$ many yogis, ${ }^{5}$ many native religions, ${ }^{6}$ and

Copyright (C) 2000 by Timothy L. Fort and James J. Noone

This article is also available at http://www.law.duke.edu/journals/62LCPFort.

* Assistant Professor of Business, University of Michigan.

** Ph.D. Candidate, Anthropology, University of Michigan.

1. Al Gini, Soul as an Ethic, 7 BUS. ETHICs Q. 157 (1997) (reviewing Allan Cox, Redefining Corporate Soul: LINKING PuRPose AND PEOPLE (1996)).

2. Yoda, THE EMPIRE STRIKes BACK (Lucasfilm-Twentieth Century Fox, 1980).

3. See II Mircea Eliade, A History Of Religious IDEAs 91-106 (Willard R. Trask trans., 1982).

4. See id. at $44-46$.

5. See generally Mircea Eliade, Yoga: Immortality And Freedom (Willard R. Trask trans., 2d ed. 1969).

6. See Vine Deloria, Jr., God is Red: A Native View of Religion 88-95 (1994); ScOtT Cunningham, Hawaitan Religion and Magic 57 (1994); Peter J. Paris, The SPIRITUAlity OF AFriCAN PEOPLES: THE SEARCH FOR A COMMON MORAL DisCOURSE 28-33 (1995). 
the Christian tradition, ${ }^{7}$ to name just a few religious sources. ${ }^{8}$ Indeed the connectedness of reality has philosophical support from Spinoza ${ }^{9}$ to Whitehead, ${ }^{10}$ as well as in the writings of many feminists ${ }^{11}$ and philosophers of science. ${ }^{12}$ The engagement with a connected, transcendent reality in these theologies and philosophies is often a starting point for formulating ethical duties. With such a pedigree, "experience the force" deserves neither ridicule nor neglect. Yet, the metaphor "force" easily can be used in ways that provide little enlightenment and, as Star Wars itself elaborates, can have both good and dark sides.

This article does not seek to formulate a theory of "business ethics according to Yoda" or of any particular theistic system. It does, however, relate business ethics to notions of transcendence found in nature and anthropology. ${ }^{13}$ Like Yoda's "force," nature-human and non-human-has a good and a dark side: It is ambiguous.

Of course, the issues at stake in formulating a corporate governance framework are a good deal more serious than science fiction. Nevertheless, the insight into ambiguity is important. Basing a metaphor on an ambiguous term can be a trap that conceals problematic assumptions and undermines "good" meaning of the metaphor. In particular, therefore, this article addresses the notion of contracts within corporate legal theory because contracts are used as a model both by those who advocate minimalist, agency business duties and by others who propound a broad business ethic. The agency use of the term by

7. See, e.g., MEISTER ECKHART: SElECTED Writings (Oliver Davies trans., 1994).

8. This list of world religions is not meant to be exhaustive. For a sustained treatment of the notion of a connecting force that lies at the basis of all religious life, see EMILE DURKHEIM, THE ELEMENTARY FORMS OF RELIGIOUS LIFE (Karen E. Fields trans., 1995).

9. See Paul Tillich, Theologian OF THE Boundaries 165 (Mark Kline Taylor ed., 1991) (noting Spinoza's claim of the inability to escape the infinite).

10. See generally Alfred NORTH WhiteheAd, Process AND REALITY: AN ESSAY IN Cosmology (David Ray Griffin \& Donald W. Sherburne eds., 1978).

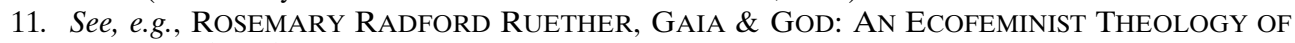
EARTH HEALING (1992).

12. See, e.g., ERrol E. HARris, Formal, Transcendental, And Dialectical Thinking: LOGIC AND REALITY (1987). Many neo-Darwinians take another approach which also stresses thoroughgoing connectedness, but in a very materialist, non-spiritual sense. See, e.g., RICHARD DAWKINS, THE BLIND WATCHMAKER (1986).

13. This article makes no claim to speak for the entirety of anthropology. Like any discipline, anthropology possesses a variety of perspectives and paradigms. Rather, the goal of this article, in part, is to present anthropology as a viable and rich resource for information on the study of humans and as a source of information on the human condition, some of which is contrary to key premises held by current contract theoreticians.

In the most general sense, as the study of humanity and culture, anthropology is perhaps best positioned among the social sciences to examine the variety of the human experience. More specifically, anthropology has grappled, since its inception, with the relationship between individuals, the environment, and culture.

What we present in this article is not by any means a cross section of current anthropological thought. It is rather a selection of significant research, readily applicable to the issues at hand and drawn from different areas within anthropology. Each selection has something important to contribute to the current debate. In addition, to facilitate informed debate and the exchange of ideas, we have chosen well-known and readily available research. 
theorists such as Frank Easterbrook and Daniel Fischel, ${ }^{14}$ F.A. Hayek, ${ }^{15}$ and Oliver Williamson, ${ }^{16}$ is quite different from its use by social-contract business ethicists such as Steven Salbu, ${ }^{17}$ Michael Keeley, ${ }^{18}$ and especially Thomas Donaldson and Thomas W. Dunfee. ${ }^{19}$

The agency theory of contracting is ultimately unpersuasive because it fails to consider adequately the cultural embeddedness of rationality and choice. Agency contractarians concentrate on a one-sided, dark notion of human nature and do not account adequately for the coercion necessary to sustain the choice that supposedly validates their approach. Similarly, social contractarians provide virtually no account of human nature and also miss the embeddedness problem. By not fully linking contracts to a transcendent reality, social contractarians provide no real reason to choose social contracting over agency contracting.

To make this argument, the article first poses a question about the use of metaphor in business ethics in Part II. This question is important for two reasons. First, ethical constructs are essentially arguments of metaphors. ${ }^{20}$ Whether one follows "stakeholder," "virtue ethics,"22 "rights," "contracts,", "naturalism," 25 or another theory, one is selecting a metaphor to describe a model for the way business ought to be conducted.

Second, it is precisely the question of metaphor that becomes problematic for a contractual approach to the corporation. In particular, nature and evolution have been used selectively as justifications for agency contractarianism. A basic problem arises when corporate governance trades upon a notion of methodological individualism that is at the heart of a nexusof-contracts approach to corporate governance. Part III elaborates the

14. See Frank H. EAsterbrook \& Daniel Fischel, The Economic Structure of CORPORATE LAW (1991).

15. See F.A. HAYeK, The FAtal Conceit (1988).

16. See Oliver Williamson, Markets AND Hierarchies: ANAlysis AND ANTITRUst IMPLICATIONS (1975).

17. See Steven Salbu, Insider Trading and the Social Contract, 5 Bus. ETHICS Q. 313 (1995).

18. See Michael KeEley, A Social-Contract TheOry OF Organizations (1988).

19. See Thomas Donaldson \& Thomas W. Dunfee, Toward a Unified Conception of Business Ethics: Integrative Social Contracts Theory, 19 ACAD. MGMT. REV. 252 (1994).

20. See JAmes M. Gustafson, Intersections: Science, TheOlogy, And Ethics 144-45 (1996).

21. See, e.g., John Boatright, What's So Special About Shareholders?, 4 BUS. ETHICS Q. 393 (1994); William M. Evan \& R. Edward Freeman, A Stakeholder Theory of the Modern Corporation: Kantian Capitalism, in ETHICAL THEORY AND BUSINESS 97 (Tom L. Beauchamp \& Norman E. Bowie eds., 3d ed. 1988); Kenneth E. Goodpaster, Business Ethics and Stakeholder Analysis, 1 Bus. ETHICs Q. 553 (1991).

22. See, e.g., RobERT C. SOlOMON, ETHICS AND EXCELlENCE: COOPERATION AND INTEGRITY IN BUSINESS 115-17 (1992); Janet McCracken \& Bill Shaw, Virtue Ethics and Contractarianism: Towards a Reconciliation, 5 BUS. ETHICS Q. 297 (1995); Jeffrey Nesteruk, Law and the Virtues: Developing a Legal Theory for Business Ethics, 5 Bus. ETHICS Q. 361 (1995).

23. See, e.g., PAtricia H. Werhane, Persons, Rights \& Corporations (1985).

24. See KEELEY, supra note 18; Donaldson \& Dunfee, supra note 19; Salbu, supra note 17.

25. See, e.g., William C. Frederick, Values, Nature and Culture in the American CORPORATION (1995). 
difficulties of this nexus-of-contracts approach when contemporary anthropological assessments of human nature are applied.

Part IV addresses the social contractarian approach. Combined with Part II's understanding of evolution and nature, a constructive model emerges that takes the best features of social contracting and agency contracting and blends them with a naturalist-based communitarianism. Part V offers a model of corporate moral theory in which legitimacy is based on the acknowledgment of a transcendent natural reality that circumscribes economic activity.

In large part, this article seeks to "mess things up." Although notions of choice and shareholder-wealth maximization can provide clear decisionmaking criteria, such notions should not be reified if they insufficiently account for the complex realities of decisionmaking. This comment is particularly applicable to agency contractarianism, wherein it is assumed that individuals seek to maximize self-interest with only marginal attention to the meaning of self. ${ }^{26}$

A dialectical epistemology that follows the work of philosopher Errol Harris $^{27}$ underpins our view of nature. By this, we mean three things. First, any description of reality must consider the relationship of the parts and the whole of the given organization. ${ }^{28}$ Any part of an entity, whether a biological body or an organizational structure, is always defined in relation to its whole, and, conversely, any whole is always defined in relation to its parts. ${ }^{29}$ A description that "brackets" or compartmentalizes phenomena does violence to the reality of the entity itself. ${ }^{30}$ Unfortunately, according to Harris, positivism in the form of mathematics and most economics describes reality in compartmentalized, unrelated units. In particular, what is bracketed are the metaphysical assumptions that provide meaning for the interaction of components of those units. $^{31}$ One way to see the application of this is as follows:

Take, for instance, the simple theorem, if $P$, then $Q . \quad P$ and $Q$ do not exist independent of a context of historical connectedness. The very $P$ that leads to $Q$ is comprised of internal relations that make $P$ itself comprehensible. In a context of pure logic, the very identity of $P$ and $Q$, as well as the relationship of $P$ to $Q$, may bracket the outside world sufficiently and remain a complete analysis of a given situation. If $P$ is a market sample, however, conducted by a corporation which leads to $Q$, which is a marketing strategy that takes advantage of the existence of $P$, the theorem is not complete. $P$ may lead to $Q$, but what does $P$ mean? What if $P$ is a set of empirical data indicating a strong demand for child pornography? That may lead to $Q$ (providing such material); but, when stripped of what $P$ means (done by bracketing moral analysis of the connection of $P$ to the reaction people have to $P$ ), neither $P$ nor $Q$ alone fully explain whether $P$ leads to $Q$. Not only is the normative question of whether we should allow child pornography to be sold left out, but there is insufficient description of reality itself. Business persons, including business

26. See Garry Miller, Ethics and the New Game Theory, in ETHICS AND AGENCY THEORY: AN INTRODUCTION 117-26 (Norman E. Bowie \& R. Edward Freeman eds., 1992).

27. See Errol Harris, Formal, Transcendental, and Dialectical Thinking: LogiC AND REALITY (1987).

28. See id. at 131-34, 250-57.

29. See id. at 132 .

30. See id. at 57-58.

31. See id. 
students, make this mistake in advocating transactions that they assume to have no relevant data other than quantifiable cost-benefit analysis. The very $P$ that leads to $Q$, however, is comprised of internal relationships that make $P$ itself comprehensible. ${ }^{32}$

Similarly, Kantian analysis also fails to describe any given whole, not because it brackets normative considerations, but because it assumes that an autonomous, subjective ego can undertake universalizing conceptions of ethical rulemaking. ${ }^{33}$

Second, a dialectical description is inherently relational. Because relationships are never fixed, a dialectical theory will emphasize context more than self-interest and duties. An emphasis on relationships and context, however, opens up a vacuum of uncertainty, which humans generally want to fill. Thus, the history of dialectical thought is frequently linked to strong accompanying, teleological constructs. This is true of Hegel's notion of Geist of human history, and the communist dialectics of Marx and Mao. ${ }^{34}$

We are not personally opposed to notions of an ultimate telos working itself to some kind of eschatological fullness in human history. We doubt human ability to describe it sufficiently to develop specific, universal criteria for determining moral action. We do believe, however, that nature provides sufficient evidence of human nature to allow and even to require normative inclusions of natural phenomena, albeit in existential terms, and does so by recognizing characteristics of human nature that constrain the choices we realistically can make.

Third, the previous two points should indicate that our dialectical approach will muddy the waters of corporate governance. Part $\mathrm{V}$ of this article sketches an alternative conception of corporate governance, but this sketch is intentionally suggestive rather than exhaustive. Part V blends scholarship from contemporary business, whose approach tends to be top-down (that is, what managers should do), with an anthropological literature looking bottom-up (that is, what is human beings need).

In particular, what human beings need to make business behavior more ethical is a more significant experience of moral empathy. That empathy, we believe, is rooted in relational experience, where individuals observe the consequences of their actions. They most markedly have such experiences in small groups. We will refer to certain instances of these small groups as mediating institutions. In contrast, contractual accounts tend to emphasize arms-length transactions against the development of moral empathy, particularly in large organizations where bureaucracy separates consequences from actions.

32. Timothy L. Fort, Corporate Constituency Statutes: A Dialectical Interpretation, 15 J.L. \& CoM. 257, 267 (1995).

33. For a critique of Kant outside of dialectical theory, see AlASDAIR MACINTYRE, AFTER VIRTUE 43-45 (1984).

34. See KEELEY, supra note 18 , at $72-75$. 
II

\section{EVOLUTION, NATURE, AND ECONOMICS IN BUSINESS}

One difficulty with using the notion of agreements as an organizing corporate metaphor is that it can mean so many different things. A simple contract is essentially a contract between autonomous strangers. ${ }^{35}$ A relational contract is an agreement among members of a community. ${ }^{36}$ A social contract is a commitment to an ideal. ${ }^{37}$ One's view of human nature influences how one characterizes the contracts negotiated by individuals, even if the agreement is a social contract. American legal history, in fact, provides an example of this anthropological assessment.

A social contract, based upon the premise that human beings are selfinterested, deceptive, opportunistic strangers, ${ }^{38}$ will produce a different ideal social contract than one founded upon a view of individuals as altruistic, noble, and committed to the common good. Some legal historians have argued that the U.S. Constitution's system of checks and balances was the result of the realization that Americans as a group were the former rather than the latter, based on the profiteering that occurred during the Revolutionary War. ${ }^{39}$ A rosy view of human nature hardly requires countervailing balances. However, an opportunistic human nature requires a social contract governed, if not by a strong Hobbesian sovereign, at least by a system that limits "evil" persons and groups from acquiring the power to abuse individual rights.

Not only does human nature affect the construction of a social contract, but the establishment of a social contract also gives rise to rules of ethical behavior that shape the moral character of the individuals subject to it. For example, a social contract ideal that corporations should provide lifelong employment to workers would have an impact on the nature of specific employment agreements. It may well foster virtues such as loyalty and trust among those working for the corporation.

The next section argues that free-market theory, as exemplified by one of its most sophisticated spokespersons, F.A. Hayek, misleadingly uses evolutionary theory to justify the superiority of the free market over collectivist structures. Section B describes how methodological individualism, in particular, misuses evolution, and Section $\mathrm{C}$ points out that this focus on individual life, like dialectical theory, provides a vacuum of purposelessness.

35. See Steven R. Salbu, The Decline of Contract as a Relationship Management Form, 47 RUTGERS L. REV. 1271, 1298 (1995).

36. See generally Ian R. MacNeil, Contracts: Adjustment of Long-Term Economic Relations Under Classical, Neoclassical, and Relational Contract Law, 72 Nw. U. L. REV. 854 (1978).

37. This ideal, for instance, could be one of autonomy, freedom, and basic human rights - the commitments made in the U.S. Declaration of Independence and the Constitution. III.

38. See Williamson, supra note 16. A more complete discussion of Williamson appears in Part

39. See DANiEl A. FARber \& SuZANNA SHERry, A History OF THE AMERICAN CONSTITUTION 16-17 (1990); GORDON WOOD, THE CREATION OF THE AMERICAN REPUBLIC: 1776$1787,114-15$ (1969). 
Hayek fills this vacuum with a teleology of the market itself, an approach that is not necessarily inappropriate in moral terms, but is not mandated by evolution, as Hayek seems to think. Section D then summarizes this misuse of evolution in relation to a more accurate way of using such evolutionary metaphors. This leads to a discussion in Section E of the constructive model that describes multi-level selection theory.

\section{A. Evolution and Economics}

F.A. Hayek often used evolutionary justifications in his free-market theory. Hayek believed that the free market offers an advance over collectivist social structures simply because it allows humanity to survive. ${ }^{40}$ Hayek, however, did not ignore the importance of moral and legal structures in the free market. $\mathrm{He}$ proposed a view of morality as a kind of cultural evolution that allows individuals to transform a collectivist sense of self-interest.

Disagreeing with Hobbes, Hayek argued that there was never a set of individuals who engaged in a war of all against all. ${ }^{41}$ Instead, human beings existed in small bands of hunters and gatherers whose instincts were collectivist and whose survival depended heavily upon basic instincts of solidarity and altruism toward members of a group. ${ }^{42}$ We have not shed these instincts, and such instincts lead to a collectivist longing for economic solidarity, ${ }^{43}$ as manifested in the theory of socialism. ${ }^{44}$ Thus, Hayek's free-market morality, which places limitations on these instincts for solidarity and altruism, is always opposed by those forced to accept such limitations. ${ }^{45}$

A central question, however, is whether living in a hunter-gatherer band is the "default state" of human society. ${ }^{46}$ In other words, is such an existence

\footnotetext{
40. See HAYEK, supra note 15 , at 70.

41. See id. at 12.

42. See id.

43. See id. at 17.

44. See id. at 19.

45. See id. at 13 .

46. The band, like any other human social organization, is largely a cultural construct, and by no means a "default state." It involves the interplay of individuals with different perspectives, wants, and needs, and the structure is continuously maintained, as are traditions and the culture itself, through
} socialization, reenforcement, and sanctions.

Additionally, "the band" is a term used to describe a type of social organization. It describes, broadly, how a group interacts, makes decisions, and perpetuates itself. The term "band" does not necessarily imply a particular economic or subsistence strategy, such as hunting and gathering. The vast majority of band societies known historically and prehistorically were mobile to some degree and were hunters and gatherers. It is also true that even in anthropological literature, the terms "band" and "hunter gatherer" often are used interchangeably. The distinction between the terms is an important one, however, and must be kept in mind to differentiate between arguments about either social organization or economic/subsistence strategies.

Researchers Richard B. Lee and Polly Wiessner provide excellent accounts of a particularly wellstudied group, the Kalahari San, or Bushmen. See RiCHARD B. LEE, THE DoBE JU/'HoANSI (1984); Richard B. LeE, The !Kung SAN: MEN WOMEN AND WORK IN A ForAging Society (1979); Polly Wiessner, Risk, Reciprocity and Social Influences on !Kung San Economics, in POLITICS AND HISTORY IN BAND SOCIETIES 61 (Eleanor Leacock and Richard B. Lee eds., 1982). In these accounts, it is clear that band organization does not depend upon, and is not predicated upon, "altruistic instinct." To the 
something to which human beings naturally fall back when not in a larger social organization $?^{47}$ In fact, anthropologists conclude that it is not. Hunter-gatherer bands are cultural constructs that serve the needs of both individuals and the group, and they must be maintained constantly through socio-cultural sanctions and reenforcement. ${ }^{48}$ As discussed more fully below, any human community depends upon cultural constructs; there is no magic differentiation in Hayek's dichotomy of natural versus civilized.

Contemporary global business clearly does not replicate small bands. Indeed, Hayek observed that we live and work in an environment in which we serve people we do not know and obey rules we have never played a part in making. In fact, we rarely understand our relationship to others regarding what we manufacture. ${ }^{49}$ In such a system, notions of cooperation and solidarity are anachronistic and at odds with contemporary civilization. ${ }^{50}$

The value of this fact, according to Hayek, is that the adaptation to living in large groups allows for an extended order (for example, a civilization) to develop, and that development allows us to survive. ${ }^{51}$ The extended order promotes self-interest better than individual experiences and understandings. Innate morality, based on solidarity, altruism, and group decisions, makes sense in small groups with similar habits and knowledge facing known problems, but it does not make sense when attempting to adapt to unknown circumstances in an extended order. ${ }^{52}$ In civilization, the important virtues form an evolved morality-consisting of values such as savings, "several property" (which essentially means contract protection), and honesty-that allow the group to discover more material resources and to obtain and preserve more from those resources. ${ }^{53}$ The logic of Hayek's market morality emphasizes virtues largely

contrary, both researchers note that in this "most sharing" of cultures, individual acts of selfishness are continually attempted. In addition, it is clear that notions such as "a good provider to the community" and "a freeloader" are commonly applied to individuals according to the community norms and standards. Thus, these ethnographic examples — of which there are many more-clearly suggest that the key to the success of the egalitarian band does not lie in a wholehearted deference to a natural collectivist instinct, but rather with the successful cultural enforcement of collectivist rules.

47. Bands are in no way considered to be isolated, or even independent, groups. Some researchers have concluded that it is quite impossible for such small groups to survive independently for any significant period of time. See, e.g., H. Martin Wobst, Boundary Conditions for Palaeolithic Social Systems: A Simulation Approach, 39 AM. ANTIQUITY 147 (1974). In addition, a primary focus of the research of bands has been the very fluid boundaries that they exhibit. Bands characteristically manifest numerous types of relationships, individual and corporate and of varying strengths and obligations, with many other similar groups. Wobst and other researchers-in particular, ROBERT Whallon, Elements of Cultural Change in THE Lower PalaeOlithic (1989)—extensively detail the reasons for this. Bands, for the purpose of this article, thus are not isolated, small groups within which individuals spend their entire lives. They are small groups within which a person functions most frequently, and which act as the primary group outside of the nuclear family within which a person is socialized.

48. See generally LEE, supra note 46 (both references).

49. See HAYEK, supra note 15 , at 14.

50. See id. at 20.

51. See id. at 70.

52. See id. at 19.

53. See id. at 70 . 
abstracted from those of a community in which individuals witness the consequences of their actions.

How do we juggle these two moralities? Hayek argued that the idea that human beings can consciously structure a fair society to juggle them is a fatal conceit. $^{54}$ Instead of reason, Hayek relied on the cultural adaptations of moral behavior found in custom and tradition: "Just as instinct is older than custom and tradition, so then are the latter older than reason: Custom and tradition stand between instinct and reason-logically, psychologically, temporally."

Hayek's position raises two concerns. First, the implications of Hayek's argument are a critique of more than socialism, but of any liberal social contractarian position favoring distributive justice. ${ }^{56}$ Thus, he challenges all social contractarian notions of business ethics.

Second, and more fundamentally, Hayek's view is on shaky anthropological ground. His statement that "custom and tradition stand between instinct and reason" $", 57$ is contrary to standard anthropological understandings of human beings. As made clear by Robert Whallon, ${ }^{58}$ and as also addressed by William Frederick's technologizing values, ${ }^{59}$ custom and tradition (for example, cultural behavior) are predicated upon, and impossible without, the human ability to abstract, to think symbolically, and to reason. The evolution of human cultural behavior, as informed by both the studies of modern and past cultures and of our primate cousins, indicates that cultural behavior and the ability to think abstractly evolved mutually and gradually. Without the ability to construct or conceive of abstract notions such as "uncle," as opposed to "this man, the brother of my mother," most mechanisms that keep groups of persons together in band-sized groups could not work. In short, one cannot make the clean differentiations within human societies that Hayek attempted; any culture requires consciously constructed social norms.

\section{B. Evolution, Economics, and Methodological Individualism}

In his deconstruction of the attempt to link evolution and economics, Geoffrey Hodgson bluntly states that Hayek "does not seem to realize that [economists'] work is not equivalent to Darwinian evolution or natural selection in a fully specified sense." ${ }^{, 0}$ There are several reasons that this statement is true. One reason is simply that social evolution is of a different character than biological evolution; analogies between the two are fraught with danger.

Hodgson points out another reason, noting that Hayek "slurs over the fact

54. See HAYEK, supra note 15 , at $66-88$.

55. Id. at 23.

56. See id. at 74.

57. Id. at 23.

58. See WHALLON, supra note 47.

59. See FREDERICK, supra note 25, at 168-208.

60. GEOFFrEy HOdGSON, ECONOMICS \& EVOLUTION: BRINGING LIFE BACK INTO ECONOMICS 152 (1996). 
that the typical story of the emergence of 'spontaneous orders,' as found in the words of the Scottish School, is ontogenetic in character. Thus, it is not strictly analogous either to a Darwinian process of natural selection or even to evolution of a Lamarckian kind." ${ }^{61}$ If Hayek's notion of evolution and natural selection were Darwinian, it would be phylogenetic in character, that is, a description of "the complete and ongoing evolution of a population, including changes in its composition and gene pool." the carrier of Hayek's evolution is the individual. Hayek therefore accepts methodological individualism and implicitly adopts the teleology of the good of the free market. Jon Elster describes methodological individualism as

the doctrine that all social phenomena (their structure and their change) are in principle explicable only in terms of individuals-their properties, goals, and beliefs. ... The individual, along with his or her assumed behavioral characteristics, is taken as the elemental building block in the theory of the social or economic system. ${ }^{63}$

Methodological individualism is contrary to the anthropological assessment of the character of individual actions. It is a long-standing tenet of anthropology that culture is an emergent property. ${ }^{64}$ That is, culture is greater than the sum of its parts. Anthropologists, who were instrumental in the construction of the anthropological concept of "culture," were very concerned with the role of the individual within groups, the primacy of the individual, and

61. Id. at 160 .

62. Id. at 40.

63. See Jon Elster, Marxism, Functionalism, and Game Theory, 11 THEORY \& SOC'Y 453, 453 (1982) (emphasis added).

64. Hayek not only defines the individual as the locus of evolutionary change, but also as the level most relevant to any incisive study of society. See generally HAYEK, supra note 15 . Durkheim and Malinowski demonstrate that, at the very least, the individual is not always the most fruitful object of study, particularly if the goal is to understand a society or culture rather than simply the actions of an individual. See generally Emile Durkheim, Rules for the Explanation of Social Facts, in HIGH POINTS IN ANTHROPOLOGY (Paul Bohannan and Mark Glazer eds., 1973); Bronislaw Malinowski, The Group and the Individual in Functional Analysis, in HIGH POINTS IN ANTHROPOLOGY 275 (Paul Bohannon and Mark Glazer eds., 1973). In fact, a broad perspective that considers a person to be, at least in part, a social creature suggests that the study of an individual as an isolated subject can never be truly explanatory or predictive because it relegates culture and society to black box status.

While more recent work has investigated the relationships between individuals and societies, Durkheim and Malinowski were included in this article for two reasons. First, the two authors shaped subsequent work: both historically and chronologically, their work offers an excellent starting point for the students of such relationships. Second, and more important, both Durkheim and Malinowski were concerned with very broad questions, which seldom have been framed as broadly since. As a result, these authors offer basic information and insight readily comprehensible, applicable, grounded in the real world based on observations. See id.

Hayek also argues that the individual is the locus of evolutionary change. Within the discipline of anthropology and particularly within the subfield of archaeology, however, a debate on the role of the individual in cultural evolution has been in progress - in its most recent incarnation-for more than ten years. Very recently, however, research has added some new insights to the debate, particularly in the realm of methodology for study. See Christopher Boehm, Emergency Decisions, Cultural-Selection Mechanics, and Group Selection, 37 CURRENT ANTHROPOLOGY 763 (1996). Boehm's article and a subsequent critical analysis by Polly Weissner effectively summarize the positions taken and the evidence used by those on both sides of the current debate. See Polly Wiessner, On Emergency Decisions, Egalitarianism, and Group Selection, 39 CURRENT ANTHROPOLOGY 356 (1998). For purposes of this article, the conclusion from this research is that it is dangerous to view biological evolution and cultural evolution as the same. 
the explanatory power of a focus on the individual. Perhaps best known is Emile Durkheim, whose concept of culture is usually translated from French to mean "collective mind" or "collective conscience." ${ }^{65}$ His basic point, which remains powerful, is that a culture is an emergent property of a group of individuals. It is not reducible to the individual, but is defined by the sum total of all of the perspectives, feelings, and behaviors of those who participate in it: "The determining cause of a social fact should be sought among the social facts preceding it and not among the states of the individual consciousness." ${ }^{, 66}$

The work of Durkheim is complemented by the work of another wellknown anthropologist, Bronislaw Malinowski. ${ }^{67}$ Malinowski makes an equally strong case for the inappropriateness of attempting to explain cultural or group behavior solely by examining individuals. Malinowski focused on the concept of institutions in society. Malinowski defined a institutions as "definite groups of men united by a charter, following rules of conduct, operating together a shaped portion of the environment, and working for the satisfaction of definite needs." ${ }^{68}$ This definition, and Malinowski's approach to the individual and culture, places institutions squarely between individuals and their needs, and between the greater society and its needs-in short, as mediators.

Despite being contrary to anthropological analyses of human society, methodological individualism has had an enormous impact on economic thought, and on corporate governance, in which individual choice is preeminent. $^{69}$ Allegedly coined by Joseph Schumpeter, "methodological" individualism focuses on the individual as the relevant datum of economic analysis. Thus, individuals and the contracts they make for their own selfinterest are the governing economic exchange. Collections of individuals, such as the corporation, are a nexus of methodologically individualistic contracts. Hodgson argues, however, that methodological individualists have provided no reason why social phenomena are individual rather than social: "It is simply arbitrary to stop at one particular stage in the explanation and say it is all reducible to individuals' just as much as to say it is 'all social and institutional.", 71

Hayek's evolutionary descriptions of the market selectively employ a metaphor in which adaptation occurs on an individual level. But this ontogenetic approach is neither consistent with the Darwinian theory on the

65. See Durkheim, supra note 64 , at 233.

66. Id. at 244 (emphasis omitted).

67. See Malinowski, supra note 64.

68. Id. at 291

69. Of course, methodological individualism is compelling, insofar as it points to a specific set of criteria and direction for decisionmaking. If one knows that one should make decisions according to profitability, then a great deal of work is eliminated in assessing other options. Such a single-minded focus is effective for many kinds of decisionmaking issues, ranging from one-issue politics to "winning isn't everything-it's the only thing" in sports to ethnic cleansing. Single-minded clarity may be powerful, but it is not morally compelling.

70. See Hodgson, supra note 60 , at 148 .

71. Id. at 155 . 
legitimacy of which Hayek trades, nor is it consistent with the spontaneous orders championed by Scottish philosophers upon whom Hayek relies for the transference of naturalist theory to free-market economics. Moreover, by ignoring standard anthropological theory, Hayek builds an economic system on the soil of an only partially described view of human nature.

\section{Teleology and the Free Market}

While some theologians and other supporters of the anthropic principle wed teleology to evolutionary processes, ${ }^{72}$ evolutionary accounts typically do not. Hayek, however, argues that the suppression of human nature's instincts is a necessary action for the rise of civilization. ${ }^{73}$ But, as Hodgson argues, "[s]urely instincts of self-interest, competition, rivalry and even aggression are part of our biological inheritance, along with other dispositions towards caring and cooperation. Hayek dogmatically assumes that we inherit one type of instinct but not the other." 74 This dogmatism is based on an ideology that evaluates political and social institutions in terms of those that maximize individual liberty within a minimalist government. ${ }^{75}$

The flaw in the kind of classic liberal utopia proposed by Hayek and Spencer is both to conceive of a perfectible type of system based on a ubiquitous kind of economic arrangement and to limit the indigenous diversity to that of agency rather than structure.... Rather than a faith in evolution towards perfection, Hayek believes that socioeconomic intervention must be pushed down a particular track precisely by the creation of institutions and "general rules" which are necessary for the formation and sustenance of the liberal utopia. ${ }^{76}$

Hodgson argues that the emphasis on nonintervention and the goodness of free markets is obscured because free markets are the dominant norm in today's economy. ${ }^{77}$ However, developing economies in the former communist block, the twin impulses of competition and cooperation run headlong into each other. $^{78}$ Free-market theorists favor a particular kind of government conducive to a particular free-market economy. Thus, use of the metaphor "evolution" and implicitly grounding the authority of the free market in natural processes demonstrates commitment to a teleological belief that free markets produce a desired state of affairs. But does nature inevitably lead to markets in which individuals freely trade and evolve? Under Hayek's own theory, they do not; their instincts first must be suppressed. What is apparent in Hayek's notions of nature and evolution is the selective, idealized aspects of nature, and the use of the rhetoric of evolutionary and natural descriptions of the world to justify free markets. Yet, nature and evolution are more complex than Hayek

72. See, e.g., ERROL E. HARRIS, COSMOS AND THEOS: ETHICAL \& THEOLOGICAL IMPLICATIONS OF THE ANTHROPIC COSMOLOGICAL PRINCIPLE (1992).

73. See HAYEK, supra note 15.

74. HoDGSON, supra note 60, at 162.

75. See id. at 181.

76. Id. at $182-83$.

77. See id. at 183-84.

78. See id. 
concedes, and that complexity has implications for the kinds of contracts individuals and groups make.

D. Metaphors of Evolution

Terms such as "evolution" have an aura of authority to them. Yet, if described incompletely, they carry that authority illegitimately. This is precisely what happens when theorists describe economic and business competition as self-interest and survival of the fittest. In fact, although a part of common knowledge, the very term "survival of the fittest" is a misnomer which incorrectly summarizes a basic concept of Darwinian evolution. More accurately, natural selection acts to prevent the survival of the unfit and, by so doing, fosters the survival of the fit. Anthropologist Kent Flannery argues that the uniqueness of humanity is that it has undergone "two fundamentally different types of evolution." "79 Biological evolution proceeds from an adaptation from a previous phylogeny. Thus, "[m]ammals arose from reptiles, which arose from amphibians, which arose from bony fishes." evolution, conversely, generates human societies in multiple ways. In Egypt and Mexico, "rank" societies evolved from autonomous villages, but in different ways and for different reasons. ${ }^{81}$ When a change to a more complex state of social organization (for example, bands to chiefdoms) fails, humans may return to the more basic band. When such a failure confronts a mammal, however, it does not return to being a reptile, but becomes extinct. ${ }^{82}$ The more basic band is not a default social institution requiring no social maintenance, but human beings can adapt to living in the prior form of society if a more recent social structure has failed.

Flannery argues that societies are more akin to organs. Eyes, for instance, have evolved independently in various kinds of animals. ${ }^{83}$ Different species' eyes did not all evolve from a common ancestor's eyes; instead, each species' eyes evolved independently from various seeing mechanisms to survive and adapt. $^{84}$ Thus, notions of evolution are useful, but the analogies must be to comparable structures. In particular, a view of economics and corporate governance that assumes methodological individualism does not account for the communal values and character of human nature. Thus, the difficulty one finds in Hayek's analysis is that he uses a powerful rhetoric of evolution to justify a socioeconomic system by only selectively focusing on certain aspects of nature. While we agree that nature and natural processes can be used in the formulation of socioeconomic considerations, they should be used with more care and complexity.

79. Kent Flannery, Prehistoric Social Evolution, in RESEARCH FrONTIERS IN ANTHROPOLOGY 3

(Carol R. Ember \& Melvin Ember eds., 1995).

80. Id. at 20.

81. See id. at 19.

82. See id.

83. See id. at 21.

84. See id. 


\section{E. Multilevel Selection Theory}

To make the evolutionary metaphor work, we would suggest that it be employed through multilevel selection theory. Part $\mathrm{V}$ provides a sketch for how one might do this but, for our present purposes, we wish to make a narrow, but important, methodological point in concluding our critique of our use of nature for business. Specific consequences of this methodology, such as understanding cooperative as well as competitive aspects of human nature, will be utilized specifically in critiquing contractarian theories. Evolutionary adaptation and natural selection take place on multiple levels. That is, adaptive selection may occur in different ways on differing levels:

$[\mathrm{T}]$ he possibility of multiple and higher levels of selection is now accepted by a number of modern biological theorists, including the possibility of selection of species and even ecosystems. There is no apparent reason why multiple levels of selection should not also exist within the socioeconomic world as well. Hayek sees selection as operating on a plurality of different groups or agencies, but seemingly always within a given [market] structure. Thus he ignores the possibility that selection may also be working at the level of structure and substructure, creating a diversity not simply of groups and agencies, but also types of economic system or subsystem as well as a variety of market forms.

The acceptance of multiple levels of evolution goes to the heart of contemporary analyses of business ethics. Methodological individualism is not a complete assessment of human nature. Hayekian free markets are not dictated by nature, nor are they inconsistent with nature. To analyze business behavior in terms of Darwinian competitive markets introduces an ideological teleology which depends on a moral justification based upon an appeal to nature that simply is inaccurate. A multilevel selection process, however, incorporates the complexity in nature and acknowledges that human nature depends upon solidarity, cooperation, and altruism as much as it does cunning, competitiveness, and struggle.

Multilevel selection theory is not new: Darwin himself recognized it. ${ }^{86}$ One can study the adaptive behavior of groups as one does individuals, but this does not mean that groups and individuals are the same things. The important task is to learn from comparisons without conflating their separate aspects. For example, individuals who practice altruism toward everyone are relatively less fit than others in the group, ${ }^{87}$ but subgroups of altruists are more fit than subgroups of non-altruists. ${ }^{88}$ The fitness of the whole group thus is enhanced by repressing the non-altruistic behavior of individuals within the group. Interestingly, the terms biologists use for the suppression of individual genes, which may have genetic adaptive advantages for the individual but which produce relatively less-fit social organisms in the aggregate, are "outlaws,"

85. Hodgson, supra note 60 , at 175-76.

86. See David Sloan Wilson, Altruism and Organism: Disentangling the Themes of Multilevel Selection Theory, 150 NATURALIST S122, S123 (Supp. 1997).

87. See id. at S122.

88. See id.

89. See id. at $\mathrm{S} 124$. 
"sheriffs," "police," "parliaments," and "rules of fairness.","

Thus, within any particular group, individuals are prevented from undertaking selfish behavior because it is in the self-interest of the individual to behave altruistically. Groups thus perform a socializing function on individuals for the benefit of both the group and the individual. The individual human body exercises social control over individual genes, but social control is at least partially necessary for both individual and group survival. ${ }^{91}$ One way this phenomenon could occur is through the development of a "group mind."

At the extreme, groups might become so integrated and the contribution of any single member might become so partial that the group could literally be said to have a mind in a way that individuals do not, just as brains have a mind in a way that neurons do not.

Human socialization, however, is not simply biology, but culture. Culture shapes individual fitness as well as the group's collective fitness. Culture is also the product, in significant part, of individual choices. Thus, it is a mistake to think that human societies, whether clans, nation-states, or corporations, operate according to deterministic, naturalistic, evolutionary processes identical to that of cells and genes. But the importance of a group's fitness to an individual's own fitness is apparent in both cases. Individual relationships with the community can be identified, but their particular manifestation differs at differing levels of adaptation.

The community, however, may require significant sacrifice from its individual members. Wilson argues that "[v]irtually all individual-level adaptations evolve in the form of genes that benefit the collective at little or no cost to themselves. Yet, when individuals benefit their groups at little or no cost to themselves, these traits are not classified as group-level adaptations." This argument is a trap. It overlooks the adaptive group advantages that influence individual choice. For example, one study shows that buffalo herds engage in a form of communal decisionmaking similar to that of honeybees even though, unlike honeybees, the buffalo do not share nearly as tightly related a kinship breeding. ${ }^{95}$ Once in the "same boat," individuals are benefited by acting in the interest of the "boat." "Nevertheless, there are times when group altruism is not smart-for example, if the group surrendered itself voluntarily to a pack of wolves. In short, the analysis cannot be reduced to that of either the group or the individual. A more complex dialectic is at work: Individual welfare and individual identity are tied to a social nature.

In terms of business, then, rejecting Hayek's misuse of the market as the

90. Id.

91. See id. at S126.

92. Id. at S128. For a good overview of organizational theory literature on these matters, including that of a group mind, see James P. Walsh, Managerial and Organizational Cognition: Notes From a Trip Down Memory Lane, 6 ORG. SCI. 280 (1995).

93. Wilson, supra note 86 , at S128.

94. Id. at $\mathrm{S} 126$.

95. See id. at $\mathrm{S} 132$.

96. See id. 
natural individual construct eliminates the ideological teleology coercively requiring a nexus-of-contracts view of the corporation. The corporation is more complex than the description given by methodological individualism and the nexus-of-contracts theory. The corporation is also comprised of social beings who value many things besides the bottom line.

This analysis leads to two important preliminary conclusions. First, behavior that benefits an individual often is related to that which benefits the group, and behavior that benefits the group often benefits the individual. In fact, an individual always exists within some greater group context, a culture or the environment generally. One must relate the individual to her community and, dialectically, the community to the individual.

Second, norms of behavior will have a different content depending upon the nature of the "same boat" in which individuals find themselves. The same rules of behavior do not apply to individuals who live within the same group and those who live among different groups. Rules of behavior well-suited to one level are not necessarily suitable to another. For instance, a rule may require that an individual tell the truth to others. Within the context of a tightly knit group, this rule may well lead to efficient, adaptive behavior. Selling a used car to one's nephew requires honesty; otherwise, the community (in this case, the family) will punish the dishonest uncle. However, to require the same uncle to be equally honest to a carjacker, or even a car dealer, applies the rule of honesty in a context in which its meaning, as well as its adaptive benefits, are quite different. ${ }^{97}$

With this as background, we can now see how contractual notions of the firm are dangerous, because they do not fully account for the social nature of human beings. Thus, a notion of autonomous individuals negotiating a real or a hypothetical contract is immediately trading on an assessment of human nature that can be strongly challenged anthropologically.

Contract analogies fall prey to the dangers of the misuse of metaphor. Agency contractarians, like Hayek, presuppose a methodological individualism that is not justified by human nature. Social contractarians fall into a similar trap because their theory of contract also insufficiently considers nature and culture.

97. This conclusion too is borne out in anthropological literature. In many discussions of trade among aboriginal populations, it has been observed that strict rules of fairness and behavior are enforced with great strength close to home, but that with social and geographic distance, the enforcement of such rules diminishes. See Douglas L. Oliver, A Solomon Island Society: KINSHIP AND LEADERSHIP AMONG THE SiUAI OF BOUgAINVILle (1955); MARSHALl SAHLinS, STONE AGE ECONOMICS (1972) (particularly ch. 5). Both authors discuss the importance of good relations with those who are most important. Sahlins offers a succinct summation of the situation:

[There is] a tendency for morality, like reciprocity, to be sectorally organized in primitive societies. The norms are characteristically relative and situational rather than absolute and universal. A given act, that is to say, is not so much in itself good or bad, it depends on who the "Alter" is. The appropriation of another man's goods or his woman, which is a sin ("theft," "adultery") in the bosom of one's community, may be not merely condoned but positively rewarded with the admiration of one's fellows-if it is perpetuated on an outsider.

Id. at 199. See also infra note 190. 
III

\section{THE CORPORATION AS A NEXUS OF CONTRACTS}

In this part, we make two main arguments. In Section A, we describe the nexus-of-contracts theory of the firm, relate it to the assumptions Hayek uses concerning the free market, note the narrow sense of responsibility suggested by this approach, and assess the ways in which exemplars of this approach utilize aspects of human nature. Section B provides three critiques of agency contractarianism: a lack of attention to social embeddedness, an incomplete view of human nature, and the lack of attention directed at the level of coercion necessary to sustain the freedom of the market. Section $C$ summarizes the assessment of agency contractarianism.

\section{A. Microcontracts on the Corporate Level}

The nexus-of-contracts theory is the predominant theory of today's modern corporation. Simplifying a great deal of legal history, the contemporary theory states that "[e]verything to do with the relation between firm and the suppliers of labor (employees), goods and services (suppliers and contractors) is contractual." "98 In step with free-market economic theory, autonomous individuals are freely able to choose whether to form a company, to be an employee, investor, or other constituent, and to accept the responsibilities accompanying such roles. ${ }^{99}$ Indeed, the freedom of individuals to choose is one of the justifications typically offered for the moral legitimacy of a contractual approach. In addition to the moral justifications, however, there are other important questions to consider: With whom do people contract, what responsibilities do corporations then bear, and when, if ever, does contract not work.

1. Justification of Contracts. The ability of those associated with the corporation to choose freely is a central justification for traditional contract theory. For example, in perhaps the leading contemporary articulation of the theory, Fischel and Easterbrook argue that this freedom includes the power to put things other than profits first:

If the New York Times is formed to publish a newspaper first and make a profit second, no one should be allowed to object. Those who came in at the beginning consented, and those who came later bought stock the price of which reflected the corporation's tempered commitment to a profit objective.... If [another] firm suddenly acquired a newspaper and declares that it is no longer interested in profit, the equity investors have a legitimate complaint. It is a complaint for breach of contract, not for derogation from some ideal of corporate governance. ${ }^{100}$

Business ethics scholar John Boatright turns the common presumption that corporations should maximize shareholder value on its head when he argues

98. EASTERBROOK \& FISCHEL, supra note 14, at 16.

99. See Ian Maitland, The Morality of the Corporation: An Empirical or Normative Disagreement?, 4 Bus. ETHICS Q. 445 (1994).

100. EASTERBROOK \& FISCHEL, supra note 14, at 36. 
that because the theory itself is indifferent to financial structures, the theory then is also open to the consideration and protection of other constituents. ${ }^{101}$ This is exactly what happens, he argues, in employee and customer-owned firms. ${ }^{102}$ At the root of each of these conceptions is the notion of choice. ${ }^{103}$

Beyond this notion of choice is a related justification for the nexus-ofcontracts theory: Agency contractarianism is more efficient and produces more material goods and services. This notion is commonplace, as verified by nearly any examination of market activities. Consistent with Hayek's free-market capitalism, efficient companies tend to be profitable. Boatright acknowledges this fact when he writes that "[a]lthough many structures are possible, some are more efficient than others, and over time more efficient structures tend to predominate through a Darwinian struggle for survival."104 Because corporations are adept at producing more material goods and services, however, Fischel and Easterbrook argue that shareholder profitability also benefits stakeholders other than the shareholders because "each party to a transaction is better off. A successful firm provides jobs for workers and goods and services for consumers." situations involving plant closings, because the benefits to "workers and communities in the new locale ... must be greater, or there would be no profit in the move." 106 Their view, of course, assumes that the only reason a company would, in fact, relocate is for economic reasons, and treats particular constituents as having interests in the corporation that are freely exchangeable.

2. Limited Responsibility of the Corporation: Two Masters or Too Many Masters. Fischel and Easterbrook assert that the normal model of corporate responsibility in agency contractarianism is maximizing shareholder welfare. To do anything else, such as to consider the impact on nonshareholder constituents, would be to serve too many masters: "[A] manager told to serve two masters (a little for equity holders, a little for the community) has been freed of both and is answerable to neither." erroneous. Corporate executives do serve multiple masters, including shareholders, creditors, and a variety of political officials. ${ }^{108}$ Serving more than one master is part of the job. There may be a point, however, at which too many masters results either in gridlock or in the enhancement of managerial

101. See John R. Boatright, Business Ethics and the Theory of the Firm, 34 AM. Bus. L.J. 217, 22223 (1996).

102. See id.

103. See John Hasnas, The Normative Theories of Business Ethics: A Guide for the Perplexed, 8 Bus. ETHICS Q. 19 (1998). Hasnas points out that the stockholder approach of Fischel and Easterbrook, the stakeholder approach of Boatright, and the social contract approach in Part IV all rely upon a notion of consent to justify moral obligations.

104. Boatright, supra note 101 , at 223.

105. EASTERBROOK \& FISCHEL, supra note 14, at 38.

106. Id. at 38-39.

107. Id. at 38 .

108. See Jonathan R. Macey, An Economic Analysis of the Various Rationales for Making Shareholders the Exclusive Beneficiaries of Corporate Fiduciary Duties, 21 STETSON L. REV. 23 (1991). 
power by an executive shrewd enough to play various constituencies against one another. ${ }^{109}$ On the other hand, it is dangerous to undermine a successful institutional organization by "do-gooding" treatment of other constituencies. ${ }^{110}$

Against what potential dangers must a contract theory protect? For Fischel and Easterbrook, the key problem is the possibility that managers can take advantage of investors. ${ }^{111}$ Investors hold firm-specific assets in the corporation in the form of shares of stock. Boatright notes, however, that other constituents also have firm-specific assets:

If the total rents or quasi-rents fail to cover the promised wages or leave too little for shareholders, then the investment might be considered a failure by the shareholderseven if the firm is highly profitable as measured by the rents and quasi-rents generated by the firm. In such a situation, the shareholders might prefer to liquidate the firm rather than deliver on the promises of higher wages, and the shareholders could not be held to these promises because of their limited liability. In short, shareholders can close down an otherwise profitable firm that generates great wealth for its employees and society at large merely because the profits are flowing to these other groups instead of the shareholders themselves. ${ }^{112}$

Thus, Boatright argues that employees, like shareholders, are residual claimants. $^{113}$

What these two positions demonstrate, at least in part, is what Eric Orts calls "shirking" and "sharking." " Shirking refers to the fears that employees will not fulfill their obligations to those who employ them. ${ }^{115}$ Sharking refers to the abuse of power by those who control the organization by taking actions that benefit some individuals rather than the entire firm. ${ }^{116}$ Both Easterbrook and Fischel's position and Boatright's position are concerned that some members of the firm will take benefits from or abuse the rights of a group of stakeholders who ought to be protected. The only question is who ought to be protected: shareholders or other constituencies? Beyond this common concern, albeit on behalf of different interests, is another commonality: Both assume the primacy of autonomous choice. Even Boatright's more broadly concerned model seems to include a rationally self-interested person who cannot rely on the goodness of others. But are human beings really that selfish? The autonomous individual required by the market must repress the very instincts of altruism and solidarity that could counteract shirking and sharking.

109. See Katherine Van Wezel Stone, Employees as Stakeholders Under State Nonshareholder Constituency Statutes, 21 STETSON L. REV. 45, 70-71 (1991).

110. See Stephen B. Presser, Thwarting the Killing of the Corporation: Limited Liability, Democracy, and Economics, 87 Nw. L. REV. 148 (1992) (critiquing Fischel and Easterbrook and warning of the dangers of playing with foundational corporate building blocks such as limited liability).

111. See EASTERBROOK \& FISCHEL, supra note 14, at 1.

112. Boatright, supra note 101, at 233.

113. See id.

114. Eric W. Orts, Shirking and Sharking: A Legal Theory of the Firm, 16 YALE L. \& POL'Y REV. 265 (1998).

115. See id.

116. See id. 
3. To Contract or Not to Contract. Oddly enough, some agency contractarians are more willing to consider human nature in their normative theory than are many philosophers, particularly social contractarians. Oliver Williamson, for example, discusses two fundamental aspects of human nature that accompany the traditional view that human beings act in self-interested ways. First, Willliamson follows Herbert Simon's seminal insight that human beings have "bounded rationality," and limits in the ability to communicate through language. ${ }^{118}$ Second, opportunism is "lack of candor or honesty in transactions, to include selfinterest seeking with guile." problems of uncertainty and populations of small numbers that prevent a market check on the actions of any self-interested individual.

From his analysis, Williamson concludes that firms are better constructed as hierarchical organizations than as market transactions.

The firm becomes a sole source supplier to itself for those transactions that are shifted out of the market and into the firm; relevant prices are known or, in any event, bids are presumably solicited less frequently as a result. Second, the firm substitutes a single incomplete contract (an employment agreement) for many complete ones. Such incomplete contracts purportedly economize on the cost of negotiating and concluding separate contracts. ${ }^{120}$

Williamson's theory is complex, but it is logically coherent, given presumptions of methodological individualism and a fairly limited description of human nature. He considers how to place individuals into a context in which they are the most efficient producers for an organization. That context does not mean consensus decisionmaking, nor does it depend upon notions of altruism, solidarity, or the other instincts Hayek views as inappropriate in the free market.

Williamson, however, does provide, implicitly or otherwise, a view of multilevel selection. That is, Willliamson understands that different organizing principles may be better than others, depending on the level of analysis. Among firms, or individuals acting as consumers, price generally serves as the organizing principle for decisionmaking. The same is not true within the firm:

While price system has advantages where remote parties to a transaction are not apprised or need to be apprised of details of transactions, internal organization allows parties to deal with uncertainties in part because "efficient codes are more apt to evolve and be employed with confidence by the parties. Such coding also economizes on bounded rationality." 121

For Williamson, transactional contracts serve individuals best because they encourage opportunistic representations and haggling, but a corporate system is better served without such transaction costs. ${ }^{122}$ The three advantages of

117. WilliamsON, supra note 16, at 9.

118. See id. at 21-22.

119. Id. at 9 .

120. Id. at 4 .

121. Id. at 25 .

122. See id. at 27. 
internal, hierarchical organizations are that individuals "are less able to appropriate subgroup gains" as a result of opportunism, such organizations can be more effectively audited, and an organization can more effectively resolve disputes. ${ }^{123}$ These rationales are hardly the stuff of ethical inspiration, but they demonstrate Williamson's understanding of the human need for cooperation and satisfactory work environments.

Williamson argues that atmosphere makes a difference in a transaction. ${ }^{124}$ Similarly, as Hodgson quotes, "[p]eople just do not maximize on a selfish basis every minute. In fact, the system would not work if they did. A consequence of that hypothesis would be the end of organized society as we know it."125 Arguing explicitly against the standard economic model, Williamson notes that transactions are often not neutral and instrumental; individuals require a satisfying exchange relation, so quasi-moral considerations are relevant. ${ }^{126}$ While there are quasi-moral associational benefits, increased profitability also requires checks on shirkers. ${ }^{127}$ The importance of constructing a community, however, does not alone legitimate a consensus form of decisionmaking. A peer group making decisions based on information flowing to all members, in a sort of modern band fashion, would simply overload communications and would preempt valuable time individuals could use for other purposes. ${ }^{128}$ Instead, Williamson argues, a simple hierarchy can provide the sense of community individuals need, along with the sense of cooperation necessary for a satisfying exchange experience, just as well as a peer group. ${ }^{129}$ Moreover, a hierarchy can do so much more efficiently. ${ }^{130}$

An authoritative order is usually a more efficient way to settle minor conflicts (for instance, differences of interpretation) than is haggling or litigation... In addition, outside arbitration, as compared with inside conflict resolution, has a less easy (more costly) access to the facts and tends to (1) employ restrictive rules of evidence, (2) consider the issues narrowly, from the point of view of what is actionable rather than in terms of what really is at stake, (3) cast the problem in the context of legal precedent for the class of cases to which it is related rather than in firm-specific terms, and (4) favor equity in relation to efficiency considerations where these goals are in conflict.

Thus, Williamson relies upon a conception of human nature that, while apparently one-sidedly dark, is in fact logically extended to develop a corporate governance system based on acquiescence to authority. We shall point out the moral weaknesses of this approach, but Williamson does offer a hierarchical construct that at least pays close attention to the dynamics of human nature.

123. Id. at 29.

124. See id. at 37.

125. Hodgson, supra note 60, at 4 (quoting Kenneth J. Arrow, Oral History I: An Interview, in ARROW AND THE ASCENT OF MODERN ECONOMIC THEORY 233 (George R. Feiwel ed., 1987)).

126. See Williamson, supra note 16 , at 38 .

127. See id. at 44.

128. See id. at 46.

129. See id. at 54.

130. See id.

131. Id. at 101 . 
4. Contracts with Whom? It is one thing to describe individual interactions as sets of contracts, whether relational or transactional. It is another to make a contract with an abstract entity that is the product of individual interactions. It is at this point that contracts become individual contracts with phylogenetic orders rather than ontogenetic ones. A stock market sale could be described as a transaction between two particular individuals. But the sale decision is really an interaction with a system, not a negotiation with an individual. In short, human beings contract with strangers, with community members, and with abstract entities.

Contracts can be transactional between individuals or even between corporations that bargain through their agents. Contracts can be relational as individuals or corporations negotiate over rights and duties within the context of an ongoing relationship. However, when individuals, even individual corporations, contract with systems on terms where the individual or individual corporation has only a marginal impact on the terms of the contract itself, then notions of choice, consent, and freedom used to describe individual contracts are no longer helpful.

\section{B. Three Critiques of Agency Contractarianism}

If the nexus-of-contracts theory of the firm relies upon justifications of free choice and human agency as normative rationales for its legitimacy, then an understanding of such choice and agency is necessary. In doing so, however, one again runs into the difficulty of relying upon individual choice for socioeconomic systems. We do endorse, of course, the goodness of free choice, but the reality of evolution is that organizational development is more than methodological individualism. If a model of methodological individualism is applied on a phylogenetic rather than an ontogenetic level, ${ }^{132}$ what it means to freely consent to an action can be distorted, particularly if the model uses only a partial view of human nature. The coercive nature of the system itself may be obscured.

132. See Geoffrey M. Hodgson, Economics And Evolution: Bringing Life Back into ECONOMICS (1996). In an effort to clarify the relationship between economics and evolution, Hodgson distinguishes between "ontogeny" and "phylogeny." "Ontogeny involves the development of a particular organism from a set of given genes.... [P]hylogeny is the complete and ongoing evolution of a population including changes in its composition and that of the gene pool." Id. at 40 . In an ontogenetic process, one can contemplate an organism reaching a final state, but a phylogenic process is an open, ongoing system. Free-market economists tend to think that self-interested individuals are constant and therefore immune from a phylogenic feedback mechanism that may make them want to consider something other than self-interest, such as the welfare of others in the group. The difficulty with methodological individualism is that it insists upon an ontogenetic human nature of stable, selfinterested preferences through which one can voice consent or refusal to consent while not taking into account the phylogenic feedback loops that allow any notion of consent to make sense. Moreover, since the phylogenetic process is an open, evolving system, one cannot simply rest with an ontogenetic characterization of the participants in that system. An individual certainly can consent to participate in a particular transaction, but the notion of consent is far more complex in the context of a system such as a corporate governance system. 
1. Social Embeddedness. Mark Granovetter argues that both the model of atomized individualism, resulting from the social contract theories of Rawls and Hobbes, and the "embedded" model, traced to tribal societies in which economic action is the determined result of social kinship patterns, are problematic. ${ }^{133}$ The embedded description provides an oversocialized view of human nature, while the atomized view provides an undersocialized view. ${ }^{134}$ Instead, persons have a dual nature: We both are constrained and informed by our communitarian norms and retain an ability to transcend that community. Granovetter, however, uses this dual nature to reach a new insight: In both over- and undersocialized views of human nature, an atomized actor decides and carries out economic action. ${ }^{135}$ In Hobbes's theory, for instance, the wholly atomized residents of the state of nature surrender their rights to an authoritarian power and obediently obey an oversocialized state. ${ }^{136}$ In the oversocialized condition, social influence is an external force that is internalized by the individual. ${ }^{137}$ Ongoing social relations existing outside of the mind of oversocialized persons cease to be a factor in understanding what the individual will do. ${ }^{138}$ In reality, human beings act neither as atoms outside of a social context nor as automatons slavishly following a script written for them by their community's institutions. ${ }^{139}$

Granovetter's analysis raises an important point for business ethics. Individuals are not autonomous decisionmakers, nor are they simply the product of their community. More than authoritative institutions and autonomous choices affect economic behavior. Between an oversocialized and undersocialized account of human action are concrete patterns of social relations. These patterns of relationships are often outside of any formal norm or rule and, while concrete, can be very difficult to define. For example, the trust developed between a supplier and purchaser may lead to firm loyalty, and the parties may bend the formal rules to accomplish their mutual objectives. Such concreteness is a very real contract of significant importance within a relationship and within communities. They are too specific and concrete, and too important to the participants, to be evaluated simply in terms of many generalized norms. Thus, Granovetter does not and cannot make "sweeping (and thus unlikely) predictions of universal order or disorder but rather assumes that the details of social structure will determine which is found."140 That is, the variety and complexity of the internal contracts are too varied and diverse to apply anything but the most basic universal rules. Similarly, Steven

133. See Mark Granovetter, Economic Action and Social Structure: The Problem of Embeddedness, 91 AM. J. SOC. 481, 481-82 (1985).

134. See id. at 483-87.

135. See id. at 485.

136. See id.

137. See id. at 486.

138. See id.

139. See id. at 487.

140. Id. at 493 . 
Salbu argues that international joint ventures have difficulties because "[c]ontractual terms have no absolute meaning independent of the context in which they are created; and socio-linguistic differences between contracting parties create breeding grounds for contextual ambiguities."

Extant social contracts thus cannot be only formal institutional rules, nor can ethics be left to autonomous decisionmakers. Instead, moral reflection is a mediating process within communities. Rogene Buchholz and Sandra Rosenthal aptly describe this process:

$[\mathrm{T}]$ he creativity of the individual can be contrasted with the conformity represented by the common perspective, but not with community. That which both founds and is founded upon this activity of ongoing adjustment is a community, and in its historical rootedness it develops its own particular organs for the control of the process. The ability to provide the means of mediating within the ongoing dynamics of adjustment constitutes a community of any type as a community.

This adjustment is neither assimilation of perspectives, one to the other, nor the fusion of perspectives into an indistinguishable oneness, but can best be understood as an accommodation through accepted means of mediation. Thus a community is constituted by, and develops in terms of, the ongoing communicative adjustment between the activity constitutive of the novel individual perspective and the common or group perspective, and each of these two interacting poles constitutive of community gains its meaning, significance, and enrichment through this process of participatory accommodation or adjustment. ${ }^{142}$

The difficulty with agency contractarianism is that it assumes an individual capable of free consent without attempting to demonstrate that such free consent in fact exists. From a sociological perspective, human beings develop categories of thought, choice, and meaning within a social, not autonomous, context.

2. An Incomplete View of Human Nature. Contemporary findings concerning the natural moral dispositions of primates, and studies of psychological development, prompt sociobiologists such as Frans de Waal to optimistically conclude that science is beginning to "wrest morality from the hands of philosophers." "143 Citing the work of Richard Alexander, Robert Frank, James Q. Wilson, and Robert Wright, de Waal embraces a naturalist, evolutionary account of morality. Such a focus on nature is compelling insofar as it helps to ground normative theory, but the work of sociobiology is dangerous if it precludes philosophical or theological reflection, analysis, and prioritization of natural dispositions. If the naturalists are correct that human beings develop their moral sense through small communities, however, can such an approach be reconciled with the powerful analytical tools of social contract theory?

141. Steven R. Sabu, Parental Coordination and Conflict in International Joint Ventures: The Use of Contract to Address Legal, Linguisitic, and Cultural Concerns, 43 CASE W. RES. L. REV. 1221, 1241 (1993) (internal footnote omitted).

142. Rogene A. Buchholz \& Sandra R. Rosenthal, Toward a New Understanding of Moral Pluralism, 6 BUS. ETHICS Q. 263, 268 (1996).

143. Frans DE WAAL, GOOD NATURED: THE ORIGINS OF RigHT AND WRONG IN HUMANS AND OTHER ANIMALS 218 (1996). 
Using these ideas requires great care. The difficulty with sociobiology, and perhaps evolutionary psychology, arises when it is used with excessive confidence in its explanatory power and comprehensiveness. Just as methodological individualism is too single-mindedly confident in its ability to explain life, so too is sociobiology. Antipodal to methodological individualism, sociobiology lurches to determinism with similar confidence. While making use of biological facts in our critique, we describe both the benefits and the difficulties of a human nature most at home in small groups. Because we view human cognitive abilities as evolutionary adaptive advantages, we believe that one can incorporate human nature's preference for small groups into a broader cultural construction that emphasizes its positive features rather than its negative ones. We want to offer naturalistic assessments in a provocative, rather than a definitive, form.

In his controversial book, The Moral Animal, Robert Wright argues that human beings are adapted-at this stage of our evolutionary development-not to live in our contemporary, urban and suburban environment, but in a band organization. ${ }^{144}$ The disjunction between this evolution and our current lives, he argues, results in a good deal of our contemporary psychopathology. ${ }^{145}$

Wright is not alone in noting this need for small communities. In eschewing sociobiology, James Q. Wilson argues that, while Darwinian evolutionary theory suggests that altruism is an adaptive mechanism for survival, ${ }^{146}$ the nurturing characteristics of human beings result from the development of our moral sense within small communities. ${ }^{147}$ Wilson provides several examples from experimental psychology and anthropology. He concludes that children in rural, economically simple communities with strong kinship ties are more willing to help and comfort others not only within their own group, but outside of the group as well. ${ }^{148}$ The study of these same children and the history of tribal warfare, however, indicate that such small groups have little conception of universal rights and duties and have less intense commitments to those who

144. See Robert Wright, The Moral Animal: Evolutionary Psychology And EVERYDAY LIFE 38-39 (1994) ("We aren't designed to stand on crowded subway platforms, or to live in suburbs next door to people we never talk to, or to get hired or fired, or to watch the evening news.").

145. See id.

146. See JAmes Q. Wilson, The Moral Sense 23, 40-41 (1993).

147. See id. at 50 .

148. See id. at 47-50. This concept of "sameness" is frequently and obviously operationalized among band-level groups. There are various mechanisms through which small bands maintain links with other bands, thus forming larger effective groups for dealing with various environmental and social stresses. See generally Joseph B. Birdsell, On Population Structure in Generalized Hunting and Gathering Populations, 12 EvOLUTION 196 (1958); LEE, supra note 46 (both references); WHALLON, supra note 47. Key among these mechanisms is the "fictive kinship" practiced, for example, by the Kalahari San. In these groups, tradition severely limits the number of possible names for an individual. These names are the same from band to band, and a man who enters or visits a band-even though he may not have any blood relatives among its members-is treated as a brother by any who share his name. Thus, similarities serve as the foundations for relationships between different groups. See supra notes 46-47. 
are unlike them. ${ }^{149}$ Nevertheless, Wilson argues that to a stranger in need of help, residents of "small towns are in fact and not just in legend more helpful than those [living] in big cities." with those around us, which not only leads to the development of a nurturing character, but also encourages atrocities perpetrated in the name of loyalty to our group. ${ }^{151}$

If small groups encourage nurturing, then fostering that role while reining in their destructive aspects is an admirable goal. Studies from anthropology and psychology suggest that it is a human predisposition to work in small groups. Psychologist Robin Dunbar, for example, found:

a correlation between the dimensions of the neocortex - the part of the brain engaged in conscious thought - and the size of different groupings of mammals.... In humans, Dunbar found, the size of the neocortex predicts [optimal populations of] groupings of about 150 people. This number happens to conform to the approximate number of the clan within hunter-gatherer societies; the company unit within the military; and the aggregate of employees within a business that can be managed without an elaborate bureaucracy. The figure of 150 , Dunbar writes, represents the maximum number of individuals with whom "we can have a genuinely social relationship, the kind of relationship that goes with knowing who they are and how they relate to us." 152

Many years ago, Jacob Bronowski noted that the communication skills of our hunter-gatherer ancestors were almost entirely internal. ${ }^{153}$ Colin Turnbull suggests that hunting societies are typically larger than one or two families but remain small, ${ }^{154}$ and Julian Jaynes, drawing on archeological evidence from Glynn Issac, ${ }^{155}$ estimates that the optimal number for such groups is approximately thirty. ${ }^{156}$ Peace and good relations are more important in these groups than is adjudicating rights and duties, ${ }^{157}$ and responsibility is more communal than personal. ${ }^{158}$ Norms become so embedded in the lives of individuals that the norms become constitutive of what it means to be a member of that group.

149. See WILSON, supra note 146 , at 47 . Wilson also describes several experiments in which even a seemingly trivial degree of likeness causes persons to react more sympathetically to another's plight. For instance, when a researcher planted a money order made out to charity in a "lost" wallet together with a public opinion poll filled out by the owner of the wallet, the finder was more likely to send the money order to the charity if the completed poll indicated that the owner had views similar to those of the finder. See id. at 49.

150. Id. at 49.

151. See id. at 140.

152. Gary Stix, Different Strokes, SCI. AM., Nov. 1996, at 36 (reviewing RoBIN DunBAR, Grooming, Gossip AND THE EvOlution OF LANGUAGE (1996)). Our thanks to Bill Frederick for bringing this article to our attention.

153. See JACOB Bronowski, The Ascent OF MAN 45 (1973).

154. See Colin Turnbull, The Forest People: A Study of the Pygmies of the Congo 37 (1962).

155. See Glynn L. Issac, Traces of Pleistocene Hunters: An East African Example, in MAN THE HunTER 253, 253-61 (Richard B. Lee \& Irvin DeVore eds., 1968).

156. See JULIAN JAYNES, THE ORIGIN OF CONSCIOUSNESS IN THE BREAKDOWN OF THE BICAMERAL MIND 129 (1976).

157. See TURNBULL, supra note 154 , at 118 .

158. See id. at 125 . 
The socially derived identity was by its very nature dependent on society. But in the earlier age recognition never arose as a problem. General recognition was built into the socially derived identity by virtue of the very fact that it was based on social categories that everyone took for granted. Yet inwardly described, personal, original identity doesn't enjoy this recognition a priori. It has to win it through exchange, and the attempt can fail. What has come about with the modern age is not the need for recognition, but the conditions in which the attempt to be recognized can fail.

Thus, in addition to a sociological component of human nature, there is a biological component as well. Human beings are a communal species and, to the extent organizational structure forces them into large bureaucratic groups and then justifies such systems according to an insufficient account of autonomous identity, modern society literally forces us to live in a way in which we will most effectively obtain identity.

3. The Coercion Necessary for Freedom. It is a standard rule of contracts that agreements are not enforceable if coerced, uninformed, or if the parties lack the requisite capacity to enter into the contract. ${ }^{160}$ Yet, all three are at risk in contemporary capitalism if the theory of methodological individualism is at the heart of the system's justification. Individuals do not have a full, free choice, and coercion is necessary to sustain a social order promoting the free market. As William Frederick has noted, power-aggrandizing is a naturally occurring value cluster in plant, animal, and human life. ${ }^{161}$ One need not even accept the conclusions of Critical Legal Studies to acknowledge that a legal structure concerns the coercive enforcement of values. The important point is to avoid a Hayekian confusion between what is natural and what is ideologically preferred.

The point of contention is not whether freedom and consent are good or bad values. Generally speaking, they are very good values. The question, rather, is whether freedom and consent mean anything outside the context of a culture and nature. If they do not, using them as if they do strains the metaphor of nature to contract to the point where the metaphor can be sustained only through coercion.

Individuals often are also uninformed about the decisions they make. This is, in part, an aspect of Williamson's uncertainty principle. In fact, individuals account for the lack of information, lessening the risks associated with uncertainty, but not removing uncertainty. Structures exist in the market to assist individuals to become informed and to participate in the market:

Participation in corporations is uniquely amenable to contracting because even the ignorant have an army of helpers. The stock market is one automatic helper. Employees work at terms negotiated by unions (and nonunion employees can observe the terms offered at other firms, which supply much information). ${ }^{162}$

159. Charles Taylor, Multiculturalism and "The Politics of Recognition" 34-35 (1992).

160. See, e.g., EASTERBROOK \& FISCHEL, supra note 14, at 22.

161. See FREDERICK, supra note 25, at 73-74.

162. EASTERBROOK \& FISCHEL, supra note 14, at 24. 
As with freedom and consent, recognizing the degree of information available is necessary for deciding when to bind individuals to promises.

Finally, there is the issue of capacity to make binding decisions. Bounded rationality suggests that there are limits to capacity. Most individuals who contract, however, do have the requisite ability to understand the terms of the transaction proposed to them. The embedded nature of the individual's decisionmaking must nevertheless be kept in mind.

\section{Summary of Agency Contractarianism}

These critiques of the free market do not suggest that capitalism is an illconceived system. Instead, the point is that free-market theorists have borrowed the authority of nature to justify a particular kind of capitalism, one that is not merited by a fuller understanding of nature itself. What agency contractarianism lacks is a sufficiently developed normative model of the relationships between the corporation and its stakeholders. It also lacks a sense of the "rules of the game." In other words, agency contractarianism lacks a sense of social contractarianism. A statement by Fischel and Easterbrook demonstrates both the need to appeal to such broader notions of norms and the reluctance to do so:

The normative thesis of the book is that corporate law should contain the terms people would have negotiated, were the costs of negotiating at arm's length for every contingency sufficiently low... arguments about social contracts are problematic. They are constructs rather than real contracts.... Perhaps the corporate contract, like the social contract, is no more than a rhetorical device. After all, investors do not sit down and haggle among themselves about the terms. Investors buy stock in the market and may know little more than its price. The terms were established by entrepreneurs, investment bankers, and managers. Changes in the rules are accomplished by voting rather than unanimous consent. So why not view the corporation as a republican government rather than a set of contracts? ${ }^{163}$

Indeed, why not apply social contract models of republican governments to a theory of corporate governance?

IV

\section{BUSINESS ETHICS AS SOCIAL CONTRACTING}

This part of the article assesses an approach that is significantly advanced over that of agency contractarianism-social contractarianism. Social contractarianism, however, is not without weaknesses. Thus, Section A provides a background of the social contractarian approach. Section B focuses specifically on the most advanced social contract application to business: Donaldson and Dunfee's Integrative Social Contracts Theory. Section C makes three critiques of this theory: an overly thin assessment of community, an overly thin understanding of nature, and an overly thin understanding of transcendence.

163. Id. at $15-16$. 


\section{A. Background of the Social Contract Theory of Business Ethics}

Thomas Donaldson is acknowledged as the pioneer of social contract theory in business ethics. ${ }^{164}$ Donaldson argues that in our modern social contract, corporations are given protections, such as limited liability and continuity of life, in return for being efficient producers of goods and services and for not abusing those who provide them with these rights, such as customers and employees. ${ }^{165}$ Thus, "[w]hen Donaldson places the basic contract above derivative duties, he sets the stage for a frontal assault on the conventional wisdom of much of corporate America, that shareholder wealth maximization is the great Good for business."

Michael Keeley applies social contract thinking to the structure of organizations, arguing that corporations should operate according to principles of equality, impartiality, and respect for individuals. ${ }^{167}$ Corporations ought to be organized to allow individuals to achieve personal goals within the organization rather than having collective goals imposed upon them. ${ }^{168}$ We will return to Keeley, who, we think, offers some of the most powerful critiques of a business-as-community approach of the kind we propose in Part V.

A second approach is that of extant social contracts. The two leading theorists of this approach are Thomas Dunfee and Steven Salbu. Dunfee argues that the actual legal contracts enacted by a particular community serve as a basis for moral rules. ${ }^{169}$ Thus, a business should operate by consulting the basic organizing principles of society to gain clarity on what social consensus has been reached.

Salbu has applied this approach in a number of areas. ${ }^{170}$ One example is insider trading regulation. ${ }^{171}$ Salbu argues that principles of procedural equality and legitimate mechanisms of property acquisition require an expansive, rather than fiduciary, approach to insider trading. ${ }^{172}$ In the extant social contracts view, societies have agreed upon the rules of the game, and companies should consult these principles rather than attempt to invent new principles of normative behavior.

\section{B. The Basics of Integrative Social Contracts Theory}

Donaldson and Dunfee have now joined these approaches to create a theory called "Integrative Social Contracts Theory" ("ISCT"). Donaldson and

164. See, e.g., ThOMAs Donaldson, Corporations \& MORALiTy (1982).

165. See id. at $42-54$.

166. Edward J. Conry, A Critique of Social Contracts for Business, 5 Bus. ETHICs Q. 187, 194 (1995).

167. See KEELEY, supra note 18 , at 52-53.

168. See id.

169. See Thomas W. Dunfee, Business Ethics and Extant Social Contracts, 1 Bus. ETHICs Q. 23 (1991).

170. See Salbu, supra note 17.

171. See id.

172. See id. 
Dunfee combine the power of empirical studies of business behavior with a normative evaluation of that behavior. Thus, this approach purports to take into account both the actual rules enacted by a community or society and a normative understanding of those rules.

Donaldson and Dunfee's argument is based on a normative, hypothetical, macrosocial contract of political economy and on the extant social contracts found in various commercial and noncommercial communities. ${ }^{173}$ Unlike the family, economic organizations are not natural; they are "artifactual."174 Because of human-bounded rationality and the artifactual nature of economic life, ISCT requires moral free space with room for differentiated cultural and religious norms that specify the particular rules for economic enterprise. ${ }^{175}$

Moral free space suggests that there are no universal norms. Donaldson and Dunfee address this moral relativism by proposing limits to the moral norms a community can devise. They provide a two-step analysis to provide real moral support to a community's norms. First, an authentic norm is one to which members of a community have consented in an informed way. ${ }^{176}$ Consent must be real. ${ }^{177}$ To guarantee that, Donaldson and Dunfee argue that consent must be reinforced by a right to exit the community. ${ }^{178}$ If a community has enacted norms and those norms have been freely accepted, they are then authentic. ${ }^{179}$

Relativism remains a threat: Individual communities could consent to outrageous norms. To counter this, Donaldson and Dunfee also test norms according to their legitimacy. ${ }^{180}$ Drawing on Charles Taylor's notion of "hypergoods," they introduce the idea of "hypernorms" that limit the range of norms that can be adopted by a community. ${ }^{181}$ Donaldson and Dunfee do not specify the content of these hypernorms, but they perceive a convergence of the acceptance of norms from the world. ${ }^{182}$ By requiring compatibility with hypernorms, Donaldson and Dunfee apply the philosophical model of social contract so that any particular community norms must be in accord with formal moral theory. Thus, community norms are legitimate if they are authentic and in accord with these hypernorms. ${ }^{183}$ At bottom, however, is consent: "the justificatory linchpin of any social contract method, whether the proposed contract is hypothetical or not."

173. See Donaldson \& Dunfee, supra note 19, at 259-60.

174. Id. at 257.

175. See id. at 260-62.

176. See id. at 262.

177. See id. at 263.

178. See id. at 262-63.

179. See id. at 263 .

180. See id. at 264-65.

181. Id. at 265.

182. See id. at 265-66.

183. See id.

184. Thomas W. Dunfee \& Thomas Donaldson, Contractarian Business Ethics: Current Status and Next Steps, 5 Bus. ETHICs Q. 173, 178-80 (1995). 


\section{Three Critiques of Social Contracting}

Before discussing the critiques of ISCT, it is important to note the advances Donaldson and Dunfee have made over agency contractarianism. By insisting upon a social contract in which those citizens who bargain for corporate existence-employees and customers-Donaldson and Dunfee show that stakeholders are entitled to have corporations treat them in a nonabusive way. It is not sufficient, as the agency contractarians allow, for a manager to focus on shareholder profitability with no more than an ideological assumption that doing so will reward other stakeholders. Donaldson and Dunfee's theory does consider benefits to nonshareholder constituents, making corporations accountable for all the consequences of their actions, not just those affecting a particular group.

Donaldson and Dunfee's two-step approach also has significant merit. Human beings' moral identity is shaped in communal relationships. This communitarian nature must be recognized; individual communities and cultures must have the freedom to develop moral norms according to the history of the organization and its historical interaction with the community in which it is situated. Relying only upon communities to identify moral norms, however, is tantamount to endorsing moral relativism and tribalism. Particularly in a global business environment, some global ethics are necessary for the ongoing engagement of international business. Thus, ISCT includes several worthy ideas.

There are critiques, however, that question Donaldson and Dunfee's reliance on contractual methodology to achieve the results they desire. Instead of contracts, a richer notion of nature provides a more meaningful identification of the community norms necessary for moral development-and even the hypernorms necessary for restricting tribalism. Such a notion of nature, in fact, ultimately becomes a transcendent check on corporate activities.

1. An Overly Thin Communitarianism: Consent and Embeddedness. Donaldson and Dunfee endorse the importance of community, but the view they provide of community is very thin. Sociologist Robert Nisbet, for example, writes that human social needs have been met historically by small organizations-mediating institutions. These institutions include families, guilds, local communities, and churches. ${ }^{185}$ In "such groups have been engendered the primary types of identification: affection, friendship, prestige, and recognition." ${ }^{186}$

Mediating institutions stand between the individual and the large superstructures of contemporary society. ${ }^{187}$ They provide a sense of community

185. See Robert Nisbet, The Quest For Community: A Study in the Ethics of Order AND FREEDOM 237 (1953).

186. Id. at 50 .

187. See generally Peter Berger \& Richard John Neuhaus, To Empower People: The Role of Mediating STRUCture in Public Policy (1977). 
in which individual responsibility and identity are developed. That insight has been applied notably, and most polemically politically, to institutions such as family, church, neighborhood, and voluntary organizations, which stand between the individual and the state. ${ }^{188}$ Because individuals develop their identity in such institutions, members learn that they are not autonomous beings but relational, social persons. As relational beings, our "self" is dependent upon our ethical duties. In ways very similar to those noted by Wilson regarding our attraction to family members and persons "like" us, ${ }^{189}$ persons become nurturing and affectionate toward others within the mediating institution group. ${ }^{190}$ Such organizations, even business organizations, are efficient at inculcating virtue when they view their institution as a family. ${ }^{191}$

a. Banded contracts: an anthropological evolution. Part II noted that anthropologist Kent Flannery describes the differences between biological and social evolution. ${ }^{192} \mathrm{He}$ adds a further distinction between social evolution and cultural evolution. Cultural evolution is about the "shared beliefs, values, cosmologies, ideologies, customs, and traditions that distinguish one group of people from other groups, giving it its ethnic identity." ${ }^{\text {"193 }}$ Social evolution occurs at a different level of organizational complexity, such as "when a small society based on egalitarian relationships becomes a larger society based on hierarchical relationships." ${ }^{194}$ Culture gives rise to identity; society leads to various forms of organization. Society, like an organ, undergoes a different kind of evolution than the species. Culture, however, is akin to "what biologists call divergent evolution-the rise of two or more new forms from a common ancestor."195

When societies are structured to require individuals to exist in associations other than their natural small bands, an inherent instability results from the coercive necessity of living together. ${ }^{196}$ The most basic unit of supra-familial human organization throughout prehistory was the hunter-gatherer band. ${ }^{197}$ Such bands were generally comprised of twenty-five to thirty-five persons and subsisted nomadically on wild plants and animals. ${ }^{198}$ Their structure, still common into the nineteenth century, had

[n]o hereditary differences in rank or authority and their leadership was ephemeral, based on differences in age, experience, skill, and charisma. Divisions of labor were

188. See id.

189. See WILSON, supra note 146, at 48-49.

190. Wilson acknowledges that there are also rivalries within the group, but those are different from the resistance shown to those outside the community. See id. at 48.

191. See Tom Chappell, The Soul of a Business: Managing For Profit And the Common GoOD 61-62 (1993).

192. See Flannery, supra note 79.

193. Id. at 3.

194. Id. at 4 .

195. Id. at 3.

196. See id.

197. See id. at 5.

198. See id. 
largely along the lines of age and gender, and most hunter-gathering bands had an egalitarian ethic that downplayed any differences in prestige that arose. This class of society is important as a kind of baseline for future evolution: Fifteen thousand years ago virtually all of our ancestors lived in such bands. ${ }^{19}$

The adoption of agriculture, however, led to autonomous village societies. ${ }^{200}$ Such communities, according to Flannery, were larger than the bands, but generally still displayed no hereditary differences in rank, and had no authority over smaller villages nearby. ${ }^{201}$ In some places, a third level of society, rank society, arose. ${ }^{202}$ In rank society, egalitarianism was replaced by an ideology in which individuals were unequal at birth and leaders came from a hereditary class. $^{203}$ In such societies, small villages lost their autonomy to larger nearby villages. $^{204}$ In some cases, this loss of autonomy led to an even greater amalgamation of villages under the authority of chiefdoms. ${ }^{205}$

The important question becomes how the band is transcended. If done coercively, evidence suggests that the larger group is unstable.

Once large villages begin to break down the autonomy of the small villages around them, ambitious chiefs can bring very large territories and thousands of people under their control. Because of the superior size and manpower of chiefdoms, they can usually overwhelm the autonomous village societies in their region. This is often done by raiding - a simple version of warfare - and may result in conversion of defeated villagers into slaves. Warfare among chiefdoms can be particularly nasty, involving terror tactics such as torture, mutilation, ritual cannibalism, human sacrifice, and the taking of trophy heads. ${ }^{206}$

On the other hand, if transcending bands occur for the benefit of the entire community, then the new larger group may be more productive. Yet, enlarging the group may not be for the community's collective benefit. An archaic state sometimes arose from competing chiefdoms, ${ }^{207}$ kingdoms with social strata including nobles, merchants, and slaves. ${ }^{208}$ These states could be conquered and grouped into multiethnic empires. ${ }^{209}$ The result was that "empires were the largest and least stable. Most broke down within two hundred years or less, perhaps telling us something about the upper size limits of human social organization." 210

It is difficult to not see similarities in the world of business. An interesting feature of the bands described above, moreover, is that they were founded on an egalitarianism that seems to be the historical purpose of social contracting. Decisions in bands place a premium on consensus, consent, and community.

199. Id.

200. See id.

201. See id.

202. See id. at 6.

203. See id.

204. See id. at 7.

205. See id.

206. Id.

207. See id.

208. See id. at 8 .

209. See id. at 9.

210. Id. 
The contracts of these groups are not "bounded" but "banded." In short, it is not just any community that fosters the desire to be ethical, but a small one-a mediating institution. In such a mediating institution, contracts are not based on consent alone, but have a socialized content - a banded contract.

Gregory Johnson has explored the relationships between group sizes and information processing and has shown that human beings are most efficient as decisionmakers when the group which must reach consensus consists of, on average, six individuals. ${ }^{211}$ Does this mean that business can be ethical only if limited to groups of six individuals? The answer, of course, is no.

Flannery's chiefdoms and states are, in Johnson's terminology, "simultaneous hierarchies." hierarchy are present at any given time; in essence, "offices" or positions of authority exist. Johnson has noted, however, that there is another type of hierarchy that may allow small groups to act communally without incurring the stresses concomitant with any attempt to reach consensus in large groups. ${ }^{213}$ In a sequential, as opposed to a simultaneous, hierarchy, a small group of individuals reach a consensus first, and then one of them attempts to reach a consensus with representatives of similarly sized groups. ${ }^{214}$ This sequential hierarchy allows cooperative action by large groups of individuals who do not grant differential status or power to any one member of their society. This sequential hierarchy, however, requires a popular desire or perceived need for communal decisionmaking. ${ }^{215}$ Only in such a context do community, consent, and consensus mean the same thing. Even in large corporations, therefore, relatively small communities could be created to provide the sense of moral identity necessary for business ethics. These bands-small communities within a chiefdom or multinational corporation—are mediating institutions.

b. Social contracting and mediating institutions. According to Nisbet, the Enlightenment social contract offered to guarantee freedom and equality in exchange for loyalty to the state, rather than to mediating institutions. ${ }^{216}$ Legal systems replaced private dispute resolution; taxation, regulation, and education placed the state in the role of problem-solver. ${ }^{217}$ In each legal system, the state guaranteed individuals the freedom to choose and to be treated impartially by powerful mediating institutions. Wilson goes so far as to characterize many of the dominant ideologies of the nineteenth and twentieth centuries as founded

211. See Gregory A. Johnson, Information Sources and the Development of Decision-Making Organizations, in SOCIAL ARCHEALOLOGY: BEYOND SUBSISTENCE AND DATING 87, 87-113 (Charles L. Redman et al. eds., 1978) [hereinafter Johnson, Information Sources]; Gregory A. Johnson, Organizational Structure and Scalar Stress, in THEORY AND EXPLANATION IN ARCHAEOLOGY 389, 389-422 (Colin Renfrew et al. eds., 1982) [hereinafter Johnson, Organizational Structure].

212. See Johnson, Organizational Structure, supra note 211, at 392-93.

213. See id.

214. See id. at 396.

215. See id. at 398.

216. See NISBET, supra note 185, at 134-35.

217. See id. at 89-108. 
on the replacement of the idea of commitment to a community with the idea of choice. $^{218}$

To Tocqueville, such a social contract, even in democratic form, was a dangerous thought. Protecting freedom and equality can throw a person "back forever upon himself alone and threatens in the end to confine him entirely within the solitude of his own heart.", When that happens, "the social tie is destroyed, and each workman, standing alone, endeavors simply to gain the most money at the least cost. The will of the customer is then his only limit."220 Tocqueville's concern was that the moral and political quest for equality and liberty could engender excessive selfishness and the rejection of any willingness for individual sacrifice for a common good. It could muzzle the communitarian nature of humanity, thereby undermining the very social structures necessary to develop individuals' ability to make appropriate, rational decisions based on consent.

In short, the political social contract has undermined the communities that give rise to personal identity. The same will be true in business unless a strong mediating institution preserves communal identity. By magnifying the needs of stakeholders who are now free to voice needs and to participate in decisions, the pursuit of individual needs assumes greater legitimacy because each person has an equal right to pursue such. This can be a beneficial correction to the oppressive hierarchies that communities can foster, but the pursuit of individual needs can also lead to the self-interested pursuit of economic greed that often characterizes capitalism and to politics where voting for the common good is subordinated to self-interest. Thus, sewn in the quest for freedom and equality were the philosophical and sociological seeds of self-interest disconnected from social responsibility. While freedom and consent may be good values, they cannot be abstracted from the community that gave them meaning. The meaning of consent must be mediated by a certain kind of community: a mediating institution.

2. An Overly Thin View of Nature: The Naturalistic Fallacy's Fallacy. Donaldson and Dunfee's normative position is driven by a philosophical commitment to traditional social contracting, but their commitment to incorporating empirical findings raises the question whether human beings are "hardwired" to behave ethically. More accurately, human beings may be hardwired to be social, and socialness requires the specification of the culture's ethical rules. Yet, Donaldson and Dunfee's commitment to another philosophical principle-avoiding the naturalistic fallacy-prevents them from relying on nature as a basis for morality. ${ }^{221}$

The historically demonstrated danger of the naturalist approach is that the

218. See Wilson, supra note 86 , at S232.

219. 2 AleXis De ToCQUeVILle, Democracy IN AMERICA 105-06 (Phillips Bradley ed. \& Henry

Reeve trans., 1945).

220. Id. at 50-51.

221. See Thomas Donaldson, When Integration Fails, 4 Bus. ETHICs Q. 157 (1994). 
theory becomes deterministic. Sociobiology leaves little room for individual initiative and creativity. Business ethicist Bill Frederick, who relies upon naturalist justifications to ground his approach, finds a way out of this, however: One naturally recurring characteristic of human beings is our technologizing ability. ${ }^{222}$ Technologizing does not mean only the creation of gadgets, but, more broadly, that human beings have an evolutionary adaptation to think symbolically and abstractly. ${ }^{223}$ Such thinking was first evidenced in toolmaking, when human beings took raw materials and reconfigured them for a new use. ${ }^{224}$ Human technologizing ability is also our ability to use language, to think philosophically, to interpret the world theologically, and to create cultures. ${ }^{225}$ Human beings can reconstruct and reformulate the world, and this capacity for constant change prevents Frederick's theory from becoming deterministic.

Thus, one way to reformulate business ethics is to blend economizing-our need for converting resources into productive energy-and ecologizing-our physical need to live in an integrated, interconnected community-value clusters. $^{226}$ Human beings do this by technologizing. Biological and anthropological research may inform the study of business and its ethics. Rather than attempting to explain moral values by biology, however, Frederick uses empirical evidence only to bolster the legitimacy of extant social contracts and of philosophical reflection on those contracts. With such a wellconstructed platform, Frederick is probably reluctant to rely more completely upon nature to ground business ethics for fear of committing the naturalistic fallacy.

Yet, the difficulties with the naturalistic fallacy can, at least to some extent, be overcome. First, the naturalistic fallacy is overstated. Every normative theory commits the naturalistic fallacy, at least in part. For example, in defining hypernorms, Donaldson and Dunfee rely upon a cross-cultural convergence of norms. Thus, the identification of hypernorms depends upon what norms already exist. Donaldson and Dunfee attempt to abstract these norms so that they do not immediately run afoul of the naturalistic fallacy. In fact, hypernorms are nevertheless derived from empirical evidence and, therefore, suffer the same naturalistic fallacy as any theory deriving the "ought" from what "is." This fallacy is actually a compelling feature of Donaldson and Dunfee's argument: If many cultures repeatedly articulate the same norm, that norm is evidence of a "natural law" that all persons must take into account in making moral judgments. For example, the fact that all world religions, as well as higher primates, have a social rule of reciprocity ${ }^{227}$ indicates

222. See FREDERICK, supra note 25, at 168-69.

223. See id. at 172.

224. See id. at 181

225. See id. at 185-97.

226. The power-aggrandizing value cluster-our quest for individual prestige and control—is not helpful in defining an ethical framework.

227. By a social rule of reciprocity, we simply mean that in these populations, there is a norm that 
that this norm may be stitched into our moral nature.

Similarly, social contractarians, including Donaldson and Dunfee, rely upon a fictional, rational, negotiating group or thinker, producing social agreements that are rational and are rationally articulated. However, legal philosopher Michael Perry argues that "[t]here is no noncircular way to justify [the claim that one ought to be rational] because any putative justification would be rational and thereby presuppose the authority of that which is at issue: rationality."228 There simply is no way to make our moral positions objective. Whatever criteria we use to justify our moral norms cannot be noncircuitously justified. This problem is exactly the circular reasoning problem faced by the naturalistic fallacy. Thus, all moral thinking relies on the same theoretical underpinnings as the naturalistic fallacy.

The second solution to the naturalistic fallacy is a sense of transcendence that extends beyond human cognitive abilities: If business ethics do not take into account the effects of corporate actions on nonshareholder constituents, who will object? Cannot society adopt any norm that is rationally chosen? Why choose one set of norms over another? In short, why worry about being ethical in business? The answer is notions of transcendence.

3. An Overly Thin View of Transcendence: Donaldson and Dunfee Meet Yoda. Donaldson and Dunfee are remarkably open to the influence of religion in ethical practices. They relate their approach to the compact with God in the Torah and to the imaginary agreement among members of Plato's state. ${ }^{229}$ This openness to notions of transcendence, however, should be extended further. What if ethical rules are not constituted simply by real or hypothetical negotiations, but instead are the result of dealing with something larger?

This article will begin to sketch this possibility; it does not exhaust the examples. There are, however, four universal aspects of nature with which any culture's moral norms must deal. Becoming aware of these aspects is itself an important step in ethical reflection. Yoda described achieving this awareness as "experiencing the force." 230 More traditionally, ethical responsibilities are learned through an experience with a transcendent reality, typically a religious experience. A Hindu finds his brahman-atman; ${ }^{231}$ Saul encountered Christ on the road to Damascus. ${ }^{232}$ In each, and undoubtedly in many others as well, ethical awareness comes from an experience with transcendence.

First, nature itself is a transcendent force. The naturalistic fallacy is troublesome in its "that's the way things are, so there's nothing we can do to

one should treat others as one has been treated. Some cultures may stretch that norm to require that a person should treat another as that person would like to be treated, but there is a basic notion of at least tit-for-tat reciprocity in all primate groupings.

228. Michael J. PerRy, Morality Politics \& LAW 15 (1988).

229. See Dunfee \& Donaldson, supra note 184, at 183.

230. See Yoda, supra note 2.

231. See ElIADE, supra note 3, at 46-56.

232. See Acts 9:1-31. 
change it" form. It is equally troublesome to confuse what ought to be with what is. One naturalist complains that this is exactly the problem of the political correctness movement; in its obsession with what ought to be done, it does not take into account the realities of the way people act. ${ }^{233}$ As much as some ethicists wish that human beings did not have economizing needs, the world is competitive as well as cooperative. In competition, there are losers. Society may be structured to limit loss and pain, an idea that dovetails well with ethical behavior, but it is impossible to remove reality-what nature is-from human nature; some competitive battles are part of our nature.

a. "If there is no God, then nothing is immoral." Another aspect of transcendence is Dostoyevsky's classic notion that without God, crime becomes not only possible, but inevitable. ${ }^{234}$ However one defines the identity of God, it is fundamentally a notion of an ultimate good to which human beings are ultimately accountable. For Dostoyevsky, told most famously in The Legend of the Grand Inquisitor, ${ }^{235}$ religion is dangerous because it causes people to stop thinking for themselves, preferring instead to defer their thinking to a leader. ${ }^{236}$ Individuals thus forfeit, to use Frederick's term, their technologizing ability. An equally problematic difficulty, however, is that an individually, or even socially, constructed God can become the product of rationalization and negotiation, ultimately producing rationalization of or agreement upon the "legitimacy" of crime.

It is possible, of course, to dismiss the need for some ultimate good as without grounding in reality. Naturalistic evidence, however, demonstrates that human beings have a natural reflective impulse grounded in our symbolic nature. Anthropologists trace evidence of human symbolic ability to roughly 40,000 years ago. ${ }^{237}$ At that time, not only art and language appeared, but also religious ritual. ${ }^{238}$ Indeed, as Frederick argues, at least one of the characteristics that differentiates human beings from nonhuman life is our religious, as well as other symbolic, dimension. $^{239}$ Thus, it may well be true not only that Dostoyevsky was correct that the consequences of law-and ethics-without religion are unacceptable, but also that the connection of spiritual realities and ethics is rooted in human nature and culture. In addition to the description of various forces and clusters that recur throughout all human societies, a notion

233. See MAtT Ridley, The ORIGins of Virtue: Human Instincts AND THE Evolution of COOPERATION 257-58 (1996).

234. See generally FyOdOR Dostoyevsky, THE Brothers KARAMAZOV (Richard Peveart \& Larissa Volokhonsky trans., 1990).

235. See Fyodor Dostoyevsky, The Legend of the Grand InQuisitor (V.V. Rozanov trans., 1972).

236. See DostoyeVsKy, supra note 234, at 246-64.

237. See Whallon, supra note 47.

238. See id.

239. See William C. Frederick, Moving to CSR4: What To Pack For the Trip or the Dinosaur's Next Footprint, Address Before the Social Issues in Management Division of the Academy of Management 21-23 (Aug. 10, 1996) (transcript on file with author). 
of transcendence of some kind is also necessary to ground any social ethic. If true, then there should be evidence of at least some common social ethic, of various cultures repeating the same moral norms-evidence of a more deeply rooted source, human nature, for the norm itself.

b. Other transcendences: bands and reciprocity. A third form of transcendence is the evidence that human beings are most naturally at home in band groups. Bands require and depend upon characteristics of moral behavior praised by many ethicists: equality, identity, altruism, and solidarity. In addition, the structure of the band, according to Johnson, best suits our problem-solving abilities. $^{240}$

The fact that virtually all of human history was lived in bands, and that band moral values are still considered to be important, is evidence of the enduring, cross-cultural legitimacy of those values. They are, in short, communitarian virtues. Yet, it is not in the large megastructure of society where characteristics such as equality, solidarity, altruism, and identity are formed, but in mediating institutions. More importantly, bands foster empathy. Small bands are required for moral development even in business organizations.

Moral empathy answers the question of why one should be moral. Agency and social contractarianism have trouble answering that question. Finance professor John Dobson's term "technical universe" 241 generally corresponds to what we have called agency theory. For Dobson, the theory's failure to answer the "why be moral" question reveals its intellectual incoherence:

[Technical universe] fails in terms of its own standards of logic and rationality; it conjures a business milieu of opportunistic individuals pursuing wealth maximization within a contractual nexus, yet it provides no mechanism within its construct for the adequate (that is, economically efficient) enforcement of these contracts. Without such enforcement, the rationally determined economic goal of material advancement is thwarted. In short, a dominant epistemology of individualistic wealth maximization ensures that individuals within that universe never maximize wealth; it is a classic "catch-22" scenario. As Aristotle and others have pointed out, to really achieve what is one's self-interest, one cannot directly pursue what one perceives to be in one's selfinterest; the Technical Universe lacks the philosophical sophistication to realize this.

Similarly, contemporary moral philosophy, of which ISCT is an example, has difficulty answering the question: "ISCT, like business ethics theory in general, suffers from all the internal inconsistencies and incoherence characteristic of modernity. Simply put, there is no such thing as a hypernorm. Ethics is always contextual." 243

The final, universal characteristic of transcendence is the basic moral norm of reciprocity. In human society, some variation of the Golden Rule exists in

240. See supra note 211 and accompanying text.

241. John Dobson, The ARt of MANAgEMEnt And the Aesthetic Manager: The Coming WAY OF BUSINESS (1999).

242. Id. at 59.

243. Id. at 69 . 
nearly every culture. ${ }^{244}$ Yet differences among the formulations of the notion of reciprocity are not without significance. Doing to others what they have done to you is quite different from doing to others as they would like you to do to them, or from treating others as you would like to be treated. Human societies with a moral system, however, typically will include some form of the rule of reciprocity. Thus, reciprocity may be a moral principle with global appeal.

Reciprocity is a norm even shared by some of our closest primate relatives. Frans de Waal has demonstrated that chimpanzees have sophisticated social norms of reciprocity. ${ }^{24}$ The fact that our closest animal relatives have social norms similar to our own should strengthen our commitment to our human sense of morality.

These four examples of transcendent principles demonstrate that human beings are, in fact, subject to forces beyond our control. There are forces within us that are part of our nature that must be considered when formulating ethical rules for business. Too often, hard-headed realists argue that business is "survival of the fittest." 446 However, nature is more complex than that. Nature is the survival of the fit, not necessarily the fittest. Nature is also about individuals in small bands cooperating with one another, establishing bonds that lead them to treat others altruistically, to practice solidarity and reciprocity, and to inculcate moral identity.

The forces that transcend human control, whether Yoda's force, Dostoyevksy's God, nature, or something else, are not simply the product of a contract. In a community of the right size, a banded contract reveals that our nature is about more than consent. These small mediating institutions are the best means for restructuring the modern corporation.

\section{V}

\section{CONCLUSION: BUSINESS AS MEDIATING INSTITUTION}

Before beginning our sketch-and we emphasize that it is only a sketch-of how businesses might be constructed as mediating institutions, there are two important questions to be addressed. Would we be better off not emphasizing business's attention to the human needs we have described? In other words, perhaps we should de-emphasize business's role in personal fulfillment and instead focus on providing more time for traditional structures such as family, church, and neighborhood. We prefer this alternative. Our purpose in suggesting that business become a mediating institution mainly points to the reality of business's contemporary preeminence, which may not permit a more traditional allocation of personal time. Moreover, we would suggest that given the amount of time people do work, spending it in a system inattentive to

\footnotetext{
244. See LaRue Tone Hosmer, Moral Leadership in Business 78 (1994). One can develop many nuances of the Golden Rule. In its most basic form, it simply means, "I know how I like to be treated; and that's how I am to treat others." JEFFREY WATTLES, THE GOLDEN RULE 3 (1996).

245. See DE WAAL, supra note 143, at 150-54.

246. SOLOMON, supra note 22 , at 26.
} 
human needs is problematic. Thus, although we would prefer to see less emphasis on business life as a place where personal identity is cultivated, we are pessimistic that this will occur.

Second, given the size, power, and reach of megastructures in our world, might any attempt to reconstruct multinational corporations be forced to make so many compromises as to undermine the entire point of the exercise? To this we must concede that there is no current way of knowing whether a mediating structure could be implemented, or if laws of corporate governance could be changed to facilitate such an implementation. The important point is the truth of the assessment of human nature. If we are right, then corporate law and business structures should be changed. If such change is impossible, then the impossibility should stand as a judgment on the moral adequacy of existing laws and structures.

It is clear that the current contractarian structure requires being "messed up." Robert Jackall's studies already demonstrate that large, bureaucratic structures do precious little to foster ethical business behavior. ${ }^{247}$ Moreover, as Dobson has argued, behind the pragmatic struggles to have corporations pay attention to ethics is a critical intellectual incoherence of modernity itself. ${ }^{248}$ Regardless of what one thinks about business as a mediating institution and as a pragmatic solution, it is an attempt to get to the heart of the ethical issues in business. $^{249}$

There are several analogies to business as a mediating institution. Business could be like a family, ${ }^{250}$ or compared to voluntary associations and neighborhoods. ${ }^{251}$ To some extent, businesses do form moral behavior; because they do, they provide opportunities to inculcate moral virtue if they create the proper kind of mediating institutions. ${ }^{252}$ In addition to these views, businesses can be mediating institutions from the perspective of this article's naturalist approach. In particular, banded contracts provide a richer understanding of and connection to moral virtue. The contracts to which we bind ourselves are those which connect us to moral empathy.

We specifically acknowledge that nature is ambiguous. While it is naïve to think we can escape certain hard-wired dimensions of our nature, it is also dilettante to think that our nature does not provide us with the capacity to culturally favor some kinds of behavior over others. To fail to note both is to fail to appreciate the dialectical dimension of human nature. What then might be problematic with a corporate model that is consciously holistic?

Social contractarian Michael Keeley provides many of the most persuasive

247. See Robert Jackall, Moral Mazes: The World of Corporate MANAGErs (1988).

248. See generally DOBSON, supra note 241.

249. See id.

250. See CHAPPELl, supra note 191.

251. See Elmer W. Johnson, Corporate Soulcraft in the Age of Brutal Markets, 7 BUS. ETHICs Q. 109 (1998).

252. See Timothy L. Fort, The Corporation as Mediating Institution: An Efficacious Synthesis of Stakeholder Theory and Corporate Constituency Statutes, 73 NOTRE DAME L. REV. 173 (1997). 
arguments against what he calls an "organismic" model. ${ }^{253}$ His model relies upon biological analogues, as well as a strand of anthropology, suggesting that organizations take on their own life separate and apart from the combination of the members of the organization. As Keeley rightly notes, such a conception of an organization can easily be used to de-emphasize the rights of individuals within the organization to the extent that basic human rights are abridged. ${ }^{254}$ This possibility is why he argues, for instance, that James Madison insisted upon a Bill of Rights appended to the U.S. Constitution. ${ }^{255}$ Keeley also notes that although premodern societies did not have a modern notion of rights, there were appropriate claims. ${ }^{256}$ In Hebrew society, these included rights to physical security, to basic necessities, and to participation in community governance. ${ }^{257}$ Such checks are important, according to Keeley, because they provide for a dispersal of power that safeguards participants from exploitation. ${ }^{258}$ Thus, Keeley argues that institutions which challenge managerial authority may be appropriate; these institutions may include unions and government. ${ }^{259}$

Keeley also argues that organizational models which provide members of organizations with enhanced decisionmaking control over manufacturing processes are not necessarily something to be admired. He notes that German Munitions Minister Albert Speer eschewed mechanistic organizational models in favor of "collegial decision making, fluidity of organizational structures, temporary organizational structures, and industrial self-responsibility [for local managers.]"260 Speer's approach proved productive and engendered enthusiasm among his managers. ${ }^{261}$ Of course, the workers carrying out the directives of the managers were conscripted slaves, and the munitions that were produced went to the direct service of the goals of the Third Reich. Thus, Keeley argues that contemporary managerial mantras endorsing decentralized, participatory workplaces ought not to be too quickly embraced. ${ }^{262}$ They are not an ethical panacea.

Even more problematic are shallow contemporary attempts to foster a notion of teamwork. In their analysis of paper mills, Steven Vallas and John Beck note that although firms reconstruct jobs in order to follow Total Quality Management notions of team building and decentralization, which depend upon worker involvement, the centralization of statistical analysis and the centralized determination of job requirements outside of a team-driven process simply discourage workers. ${ }^{263}$ Portraying such efforts as community building

253. KEELEY, supra note 18 , at 22.

254. Cf. KEELEY, supra note 18, at 129.

255. See id.

256. See id. at 60.

257. See id.

258. See id. at 154.

259. See id.

260. Id. at 6 .

261. See id.

262. See id. at 6-9.

263. See Steven P. Vallas \& John P. Beck, The Transformation of Work Revisited: The Limits of 
can be justified only in a contractual manner, in which it is assumed that both parties have freely consented to the new way of doing work. It is clear that efforts like those studied by Vallas and Beck have not even minimally considered what makes a community. As a result, to reject a business-ascommunity approach because of the manipulation of communities through sham quality efforts is similar to criticizing a small chamber orchestra because the large symphony that replaced it does not sound like a chamber group.

Similarly, Richard Sennett has argued that managerial models of teamwork destroy personal character because, at least in part, membership in any particular business team is temporary. ${ }^{264}$ Learning to be a team player means learning how to display certain traits of rhetoric and superficial cooperativeness. Such traits are masks appearing to demonstrate consensus. In reality, this apparent consensus is ordered acquiescence to centralized management with little relationship between identifying one's well-being and the common good of the group. ${ }^{265}$ Moreover, Sennett found that peer pressure within the groups to conform to a goal can be harsh, and the goal is typically not what the group members view as important, but simply that of enhancing the bottom line. ${ }^{266}$ This pressure effectively coerces individuals to work harder under the guise of team-action, while simultaneously exempting uppermanagement from responsibility for "cracking the whip."267 Again, such efforts have utterly no relationship to what constitutes a mediating institution, that is, a small community where members of the mediating institution have a relationship in the activities they undertake, not to the exclusion of outside goals, but neither in complete deference to the interests of such outside megastructures.

In this article, we are prepared to endorse the efforts of those attacking bureaucratic structures, but we are not prepared to do so in the name of a subsequent sole reliance on entrepreneurial initiative nor on a hegemonic gimmick of teamwork. Simply put, a choice between a centralized bureaucracy dominating individuals and gimmicky teams doing senior management's dirty work is no choice. We propose another kind of community in critiquing contractual theories of the firm.

Nowhere in any of these critiques is there a discussion about the sizes of the organizations in question. They simply present a dichotomy between individual protection and organizations. In this article, we are speaking of a community which is sufficiently attuned to human nature, and in which the goals of an individual are largely synonymous with the goals of an organization. ${ }^{268}$

Flexibility in American Manufacturing, 43 Soc. PROBS. 339, 347-48 (1996).

264. See Richard SENNETt, The Corrosion of CHARACTER: THE PERSOnAl Consequences OF WORK IN THE NEW CAPITALISM 106-17 (1998).

265. See id.

266. See id. at 113.

267. See id. at 113-14.

268. See KEELEY, supra note 18, at 98 . Keeley uses this language to distinguish between the preferences of individuals within an organization and the goals an organization has for itself. See id. 
Describing a notion of businesses as mediating institutions is a dialectical task attending to both individual and organizational dynamics of corporate life. It is not one or the other, nor is it a false choice between domination and hegemony; it is a fresh initiative.

In arguing for these small institutions, we do not advocate turning AT\&T or Ford Motor Company into contemporary hunter-gatherer bands of 150 individuals selling telecommunications equipment and automobiles. Large, multinational corporations are here to stay, and our proposal to emphasize decentralization is one made to balance bureaucratic trends with human needs, not to reject large organizations in their entirety.

The naturalist implications of business ethics begin from the premise that, "[b]iologically, we are just another ape. Mentally, we are a new phylum of organisms." analyze that distinguishes us from our closest relatives in the animal kingdom. Again, however, we are not romanticizing hunter-gatherer bands. Our banded inheritance, moreover, has risks as well as benefits.

One author has very liberally estimated that more than 100 million people have died from war-related causes (including famine and disease) on our planet during this century. These deaths could be regarded as the price modern humanity has paid for being divided into nation-states. Yet this appalling figure is twenty times smaller than the losses that might have resulted if the world's population were still organized into bands, tribes, and chiefdoms.

The aim is not to glorify our banded past, but to note its reality and to integrate its benefits into a contemporary business structure. Corporations ought to be structured to allow individuals to develop their moral identity within relatively small groups, resolve their own disputes, and have representation in the megastructures that inevitably will exist in our global, capitalistic world. The result, while similar to Donaldson and Dunfee's social contract structure, will successfully describe a more precise communitarian view of human nature.

\section{A. Small Numbers}

Robert Jackall wrote one of the more bracing books about the ethics of modern business. ${ }^{271}$ Essentially, he did field work in organizations and found that virtue was socially constructed and removed from any kind of transcendent benchmarks. $^{272}$ The rules of behavior honored the king, the CEO, ${ }^{273}$ avoided taking responsibility for mistakes, ${ }^{274}$ and exploited short-term advantages to enhance reputation with persons leaving the job before the long-term results of neglect appeared. ${ }^{275}$ Individuals were uninspired by notions of moral

269. Terrence W. Deacon, The Symbolic Species: The Co-Evolution of Language And THE BRAIN 23 (1997).

270. LAWRENCE H. KEELEY, WAR BEFORE CIVILIZATION 93 (1996).

271. See JACKALL, supra note 247.

272. See id. at 6, 65-74, 112 .

273. See id. at 17-25.

274. See id. at $75-100$.

275. See id. at 91-95. 
obligations; "[b]ureaucracy separates people from the consequences of their actions." ${ }^{276}$ The problem of bureaucracy is more familiar to business management, but is not addressed well by the law. This is seen in three respects.

First, over the past twenty years, management has recognized that it is inefficient to concentrate on bigness in the workplace. Although their structure can be abused, as we have seen, greater productivity results from decentralizing work forces and teams. In smaller groups, individuals take greater ownership over the end product, produce higher-quality products and services-precisely because they become psychologically invested in the community project-and are more innovative. The total quality movement, inspired by theorists such as Deming $^{277}$ and Juran, ${ }^{278}$ followed this insight. The movement stressed the responsibility and creativity of individuals working in small groups called quality circles. ${ }^{279}$ Similarly, a survey conducted by a Wall Street Journal columnist in 1996, found that the leading management design tool was "selforganization," also known as cellular organization. ${ }^{280}$ Such firms stress entrepreneurship, member ownership, and organization of the teams within the firm. ${ }^{281}$ Management today has accepted the fact that individuals work well in small groups. A reason for this efficiency is the natural, human, cognitive ability to be more comfortable in relatively small groups.

This is not to say, however, that it is always appropriate simply to graft this model onto a complex, interpersonal organization such as a corporation. A May 1998 Wall Street Journal article reported that one of the most noted socially responsible companies, Levi Strauss, created workplace havoc by insisting upon teams. ${ }^{282}$ When managers reflected on the causes of this problem, they concluded that the company culture simply was not ready for the transformation. ${ }^{283}$ Despite the naturalness of small groups, corporations must use the greatest care when transforming their workplace culture. There must likewise be caution in the methods chosen for instilling an authentic value of teamwork. Corporate exercises in fake para-military training designed to create immediate, interpersonal dependencies under mock conditions of warfare $^{284}$ may or may not be successful in any given corporation. The

276. Id. at 127.

277. See W. EdWARds Deming, OUt OF THE CRISIS (1986).

278. See J.M. Juran, Managerial Breakthrough: A New Conception of the Manager's JOB (1964).

279. See John S. OAKland, Total Quality Management 252-55 (1990); Mary Walton, The Deming Management Method 16, 152-53, 159, 171, 190 (1990).

280. See Raymond E. Miles et al., Organizing in the Knowledge Age: Anticipating the Cellular Form,

11 ACAD. MGMT. ExEC. 7 (1997).

281. See id. at 12.

282. See Ralph T. King Jr., Jean's Therapy: Levi's Factory Workers Are Assigned to Teams, And Morale Takes a Hit: Infighting Rises, Productivity Falls as Employees Miss the Piecework System, WALL ST. J., May 20, 1998, at A1.

283. See id. at A6.

284. See Abby Ellin, I Want to Be a Chairborne Ranger: Boot Camp for the Office, N.Y. TIMES, May 24, 1998, at BU9. 
manipulation models noted by Vallas and Sennett are not the models we advocate; nor are the models critiqued by Keeley. However, because of the abuses made of the teams, they both must exist and should exist only within a structure that can constrain unsavory dimensions. We simply advocate a better balance than what currently exists. There is no magic elixir for corporate morality and governance, but a model that matches our natural characteristics when carefully considering the extant corporate culture is more likely to be successful.

Second, legal scholars have recognized that changing patterns of global business may require changes in the theory of contract law. Steven Salbu has argued that the transactional notion of contracts worked well in the relatively stable economies of the Middle Ages, but such notions are poorly suited to a fast-paced global economy with great uncertainty. ${ }^{285}$ In an unpredictable environment, management must operate not by specifying obligations and being adversarial, but by addressing uncertainty through cooperation. ${ }^{286}$ Salbu thus stresses the development of relational contracting, with parties attempting to find win-win situations rather than win-loss alternatives. ${ }^{287}$ Interestingly, the model Salbu offers is the "functional family":

Like the family members who genuinely wish one another success, transactional allies will naturally constrain self-interest through concessions made for the ultimate good of others and of the alliance. Those who interact functionally and familially have little use for formalization of obligation, and indeed such formalization would be wasteful and ineffective.... Innovations in relationship management forms may better serve emerging, non-adversarial forms of cooperative linkages. ${ }^{288}$

Thus, contract doctrine must recognize forms of human interaction other than the adversarial, opportunistic model offered by agency contracting. ${ }^{289}$

Third, corporate governance theory must consider anthropological sources. Megastructures carry with them coercion and conflict. Flannery notes, for example, that in the late 1770s, four of the Hawaiian Islands-Hawaii, Maui, Oahu, and Kauai-had native chiefs ruling over a chiefdom. ${ }^{290}$ The competition among them, particularly that of Oahu and Maui for the smaller islands of Lanai and Molokai, produced a period of intrigue, warfare, and usurpation that ultimately allowed Kamehameha to conquer all the islands under the power of a single state. $^{291}$ Hawaii, of course, is hardly a unique example. The amalgamation of bands into larger organizations requires coercion in direct confrontation with social harmony and virtue. With multinational corporations sometimes equal in size, and often in wealth, to some nation-states, advice to

285. See Salbu, supra note 35 , at 1295 .

286. See id. at 1296-99.

287. See id. at 1303.

288. Id. at 1303-04.

289. See id. at 1297 n.89 (specifically identifying as problematic Williamson's view of the opportunistic and adversarial model of contracting).

290. See Flannery, supra note 79, at 15.

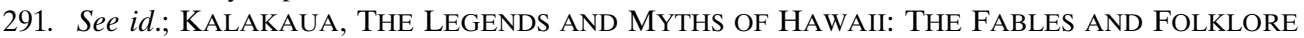
of A STRANGE PEOPle (R.M. Daggett ed., 1888). 
political organizations is equally applicable to business:

If we are to recover social harmony and virtue, if we are to build back into society the virtues that made it work for us, it is vital that we reduce the power and scope of the state. That does not mean a vicious war of all against all. It means devolution: devolution of power over people's lives to parishes, computer networks, clubs, teams, self-help groups, small businesses-everything small and local. ${ }^{292}$

There is, therefore, a need to restructure workplaces into communities of relatively small groups that can foster a sense of moral virtue and identity. In these places, individuals can acquire a self-interest that is more than opportunistic behavior and is connected to the common good. A central virtue for business is equality, a key virtue in any social contract. "In hunter-gatherer societies, nobody must be allowed to become big-headed." individualistic entropy, the maintenance of egalitarian norms is crucial to band selection. $^{294}$ Norms of equality, solidarity, and altruism will not be found in big bureaucratic institutions, but in small groups in which individuals in bands negotiate the relational rules that create win-win rather than win-lose contracts.

\section{B. Dispute Resolution}

As noted in Part III, one of the central ways in which nation-states, using Enlightenment social contract theories, undermined prior institutions was by settling disputes. ${ }^{295}$ Dispute settlement occurred in English legal history, not only in the development of the common law, in which juries gradually were formalized into formal adjudicating mechanisms rather than simple communal peer decisionmaking, ${ }^{296}$ but also when royal justice replaced local justice. ${ }^{297}$

There is a risk, however, in relying upon outside sources for resolving disputes. External power literally foreign to the small community can undermine the communal dynamic. In some nonfunctional situations, such as a family engaged in child abuse, outside power is necessary. However, if too readily available, outside intervention can also rend the fabric of a functional community.

Anthropologist Gregory Johnson argues that decisionmaking becomes progressively less efficient in groups of more than six. ${ }^{298}$ This number is far smaller than even the very small size of bands, usually twenty-five to thirty-five individuals. Yet, as Johnson notes, bands also rely on face-to-face consensus. ${ }^{299}$ Creating relatively small, autonomous groups thus facilitates dispute resolution without turning to outside dispute resolvers, such as the courts, which might undermine the community itself.

292. RIDLEY, supra note 233, at 264.

293. Id. at 244 .

294. See id.

295. See NISBET, supra note 185, at 237 and accompanying text.

296. See J.H. BAKER, AN InTROdUCtION to ENGLiSH LEGAL History 63-66 (2d ed. 1979).

297. See id. at 21-27.

298. See Johnson, Organizational Structure, supra note 211, at 392-95.

299. See id. at 395-96. 
Johnson's research displays the possibility that societies and groups larger than band-size may continue to make decisions effectively based on consensus. Although his research focused on the organization of pre-historic groups, Johnson's conclusions are fundamental to any understanding of human social organization; his findings are as applicable to contemporary as to ancient populations, and provide insight into alternative, nonhierarchical organizations for large groups. One of the most interesting and relevant conclusions of his research is that it is possible to maintain face-to-face interaction and consensusbased decisionmaking within relatively large social units through sequential hierarchies. ${ }^{300}$ Small groups each provide a representative to a meeting of the representatives of several small groups. The individual need not be elected, granted any special rights or privileges, or invested with any authority other than to speak for his or her group. Similar meetings occur "up the line," until the result is a final decision based on consensus-a decision that has incorporated the positions of many individuals, but that never required the simultaneous consensus of all.

A major strength of Johnson's work is that it is supported by other lines of research. Many anthropologists and other researchers have noted very consistent group sizes among aboriginal populations, around twenty-five to thirty-five persons in a band and around 450 to 600 in a "macroband," the largest population which regularly interacts. ${ }^{301}$ These average numbers, given the vast array of environmental and social variables found throughout the world, are surprisingly consistent. A powerful explanation for this consistency is Johnson's research on group consensus: A band is a number of nuclear families interacting effectively, without forming too large a group. With the aid of various integrative institutions, such as rituals and the formation of task groups with specific responsibilities, the use of sequential hierarchies allows multiple bands to coexist and function cohesively at the level of the macroband. ${ }^{302}$

That human macroband populations include around 500 individuals is most likely the result of effective compromise between the stresses of scale and the needs of human populations for diversity and numbers sufficient to ensure autonomous success. Martin Wobst has pioneered the investigation of cultural effects on population sizes, and its concomitant effects and implications for population success. ${ }^{303}$ Wobst has determined that a group must contain approximately 500 individuals to ensure that each generation of adults may find partners, enabling the population to survive. That number coincides with what Birdsell—and the many researchers who have followed his lead-has observed for macroband populations in Australia, and which he correlated with linguistic

300. See supra notes $217-218$ and accompanying text.

301. For an early but thorough examination of this issue, see Birdsell, supra note 148, at 196-99.

302. For a brief but thorough discussion, see LEE, supra note 46 (both references); Johnson, Organizational Structure, supra note 211, at 405-06.

303. See Wobst, supra note 47. 
boundaries. $^{304}$ Thus, functional populations of hunter-gatherers of 500 individuals are well documented, and even though they employ consensual decisionmaking, sequential hierarchies allow this to work successfully for many groups. We only suggest these notions to provoke thought. Clearly, a more extensive elaboration of how these structures might be implemented in business organizations requires much more extensive attention. The important point, however, is that naturalistic categories demonstrate transcendent realities of human life. Anthropological research provides categories that account for these communal realities while avoiding the abuses teams and the like have suffered. The difference is between a "team" and a mediating institution.

Anthropology, therefore, helps explain how human societies can construct themselves, even in large megastructures, while preserving community identity within small mediating institutions. This insight is important for designing not only structures to minimize disputes and foster communal identity, but also corporate governance structures.

\section{Federated Corporate Governance}

It is unrealistic for corporations to devolve into small bands of workers. We live in an age of global, multinational corporations with thousands of workers in dozens of countries. Yet, efficiency, productivity, and creativity are enhanced when individuals are placed in small, problem-solving mediating institutions. $^{305}$ It is now important for scholars of corporate governance to recognize that these small units are successful for anthropological reasons and have moral significance.

Agency contractarianism, relying on contracts bargained between autonomous negotiators, cannot explain the success of small groups. Instead, the theory of banded contracts, in which contracts themselves have a different nature because of the agreement's social context and the communal identity of individuals forming the contracts, provides a better analysis. A communal sense does not result from a community of any size, however, as Donaldson and Dunfee's theory seems to assume, but only from a community of relatively small numbers.

As in Integrative Social Contracts Theory, the notion of business-asmediating-institution recognizes the importance of community contracts and overarching norms to control the tribal excesses that small communities could indulge. The notion of a community in business-as-mediating-institution theory, however, has specified requirements to accord with human nature: small numbers, internal group dispute resolution, and individual participation.

Beyond these community norms, cross-cultural norms must also be identified. One such norm might be a notion of reciprocity, the content of

304. See id.

305. See supra notes 277-281 and accompanying text. 
which will vary according to the level of selection. Within a mediating institution, reciprocity may mean treating others as the actor would like to be treated. Among institutions or among the individual representatives of institutions in a sequential hierarchy, reciprocity might be "generous tit-fortat," negative outcomes to prevent a degenerative cycle of retribution and revenge. Undoubtedly, there are other cross-cultural norms, such as participation in group decisionmaking, ${ }^{307}$ which suggest a greater role for employees on boards of directors. $^{308}$ In every norm, the ongoing tension between the recurring limitations of human nature and the human symbolic technologizing ability to recombine and recreate to find new structures of organization will persist.

Moreover, despite our concerns regarding the methodology Donaldson and Dunfee use to develop Integrative Social Contracts Theory and the resulting categories that accompany this methodology, we believe that the approach we describe is at least complementary to, if not largely consistent with, the "Marketplace of Morality" argument made in this special issue by Thomas Dunfee. ${ }^{309}$ We agree with Dunfee that a monotonist view of corporate responsibility is too narrow because stakeholders, to whom a corporation must pay attention, have interests beyond that of shareholder wealth maximization. This is true for the complex anthropological reasons we have developed in this article. More importantly, Dunfee lists four guiding principles for corporate managers:

(1) There is a presumption that all corporate actions must be undertaken to maximize shareholder wealth;

(2) Managers must respond to and anticipate existing and changing marketplace morality relevant to the firm that may have a negative impact on shareholder wealth;

(3) The presumption in Principle One may be rebutted where clear and convincing evidence exists that marketplace morality relevant to the firm would justify a decision that cannot be shown to maximize shareholder wealth directly; and

(4) Managers must act consistently with hypernorms (manifest universal norms and principles).

Having already indicated our attraction to and concerns with hypernorms, we simply wish to indicate that Dunfee's first three principles may be best implemented by a structure that provides significant autonomy to the groups within the corporation, whose sizes are such that they match up with human cognitive capacities to process a limited number of relationships. Such groups should have a primary voice in determining the actions of managers of the corporation.

306. See Robert M. Axelrod, The Evolution of CoOperation 211, 1390 (1984).

307. See John Finnis, NATURAL LAW AND NATURAL Rights 146-47 (1980).

308. See Fort, supra note 252, at 201.

309. See Thomas W. Dunfee, Corporate Governance in a Market with Morality, 62 LAW \& CONTEMP. PROBS 129 (Summer 1999).

310. Id. at 156-57. 
One article could not describe all of the dimensions of viewing businesses as mediating institutions and the impact of such a view on corporate governance. Instead, the purpose of this article has been narrow, but important: Scholars should be careful when using nature and evolution to justify socioeconomic structures, but there is also a reward in doing so.

In particular, contrary to the use often made of evolution and nature, anthropological research indicates that human beings are most adapted to living and working in the small organizations where their cultural and moral identities are formed. Human beings should not be viewed simply and only as autonomous contractors as agency contractarians do. It risks undermining moral identity to force communal human beings into bureaucratic structures.

Social contracting theory also must be supplemented by a much more explicit understanding of the communal nature of human beings. That understanding is best gained by learning from those who specifically study human nature. The small mediating institutions necessary to nurture our natural communal identity require specific forms of corporate structure before the social contract theory can begin to analyze the authenticity of norms provided by other communities and to draw upon norms from around the world. Moreover, without a sense that not everything can be negotiated and without a sense of a transcendence, social contracting provides little justification for being ethical. Thus, an important first step is to recognize the interconnected identity of human beings with each other and with nature as a whole. Such an experience may not replicate Yoda, but it will change the way we look at business. The second step is to recognize the importance of size. While "size matters not" in the access to transcendent power, it does matter to human moral identity for very transcendent, natural reasons. 